\title{
AVALIAÇÃO DO RESÍDUO DE CERVEJARIA EM DIETAS DE RUMINANTES ATRAVÉS DE TÉCNICAS NUCLEARES E CORRELATAS.
}

\section{SERGIO LUCIO SALOMON CABRAL FILHO}

Dissertação apresentada ao Centro de Energia Nuclear na Agricultura, da Universidade de São Paulo, como requisitos para a obtenção do título de Mestre em Ciências, área de concentração: Energia Nuclear na Agricultura

PIRACICABA

Estado de São Paulo - Brasil

Dezembro - 1999 


\section{AVALIAÇÃO DO RESÍDUO DE CERVEJARIA EM DIETAS DE RUMINANTES ATRAVÉS DE TÉCNICAS NUCLEARES E CORRELATAS}

\section{SERGIO LUCIO SALOMON CABRAL FILHO}

Zootecnista

Orientador: Prof. Dr. ADIBE LUIZ ABDALLA

Dissertação apresentada ao Centro de Energia Nuclear na Agricultura, da Universidade de São Paulo, como requisitos para a obtenção do título de Mestre em Ciências, área de concentração: Energia Nuclear na Agricultura

PIRACICABA

Estado de São Paulo - Brasil

Dezembro - 1999 
Dedico:

Aos meus pais, pelo esforço para a minha formação, A minha esposa e filha pela dedicação e paciência, o presente trabalho 
Agradeço a todos que de alguma forma contribuíram para a realização desse trabalho. Em especial expresso minha gratidão às seguintes pessoas:

Ao Prof. Dr. Adibe Luiz Abdalla pelo incentivo e orientação na execução do trabalho;

Ao Centro de Energia Nuclear na Agricultura, por conceder-me a oportunidade da realização dos meus estudos;

À FAPESP, por financiar os estudos através do apoio financeiro concedido;

À equipe de pesquisadores do Laboratório de Nutrição Animal do CENA pelo incentivo;

Aos colegas Ives C. da Silva Bueno, Sarita S. Gobbo, Eduardo F. Nozella e Mariana Machado pelo auxílio na condução do experimento, estímulo e amizade;

Aos funcionários Lécio A. Castilho e Maria Regina S. R. Peçanha pela colaboração no trabalho com os animais e auxílio nos procedimentos analíticos realizados;

Aos estagiários Graziele Chorilli, Wagner e José pela ajuda oferecida sempre que necessário. 


\section{SUMÁRIO}

Página

LISTA DE TABELAS ……......................................................

LISTA DE QUADROS …........................................................iii

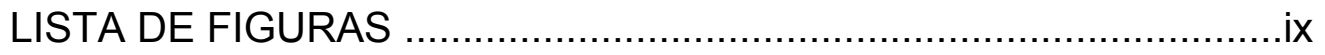

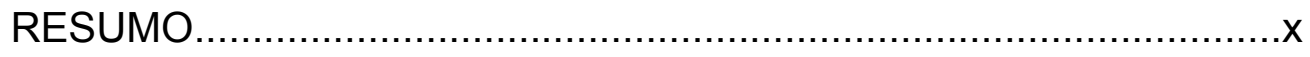

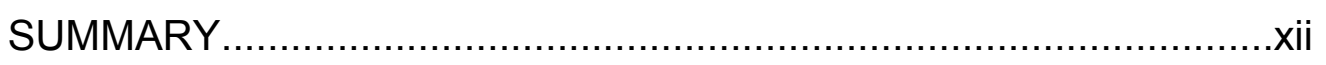

1. INTRODUÇÃO

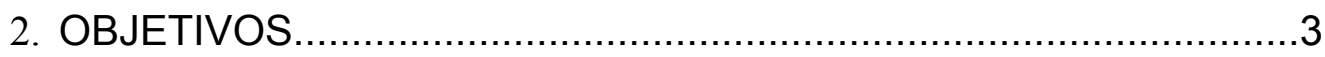

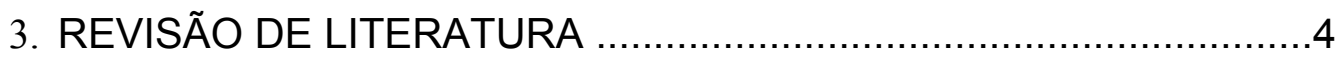

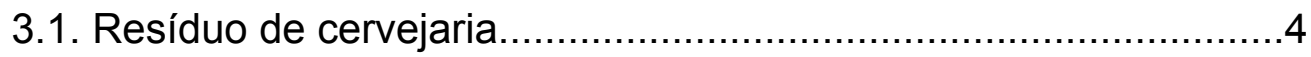

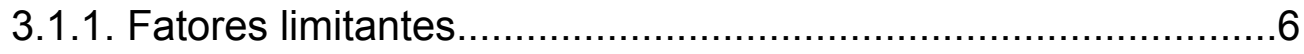

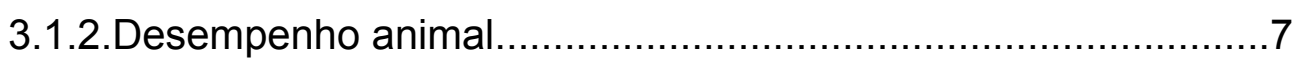

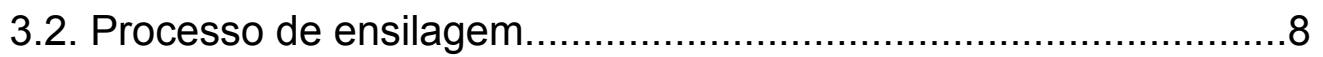

3.3. Fibra de subproduto em dietas de ruminantes........................... 9

3.4. Métodos de avaliação dos alimentos...........................................11

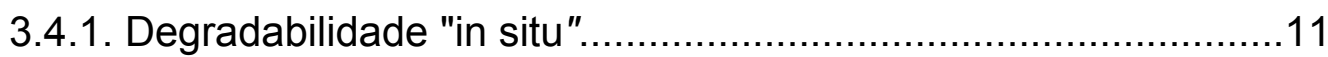

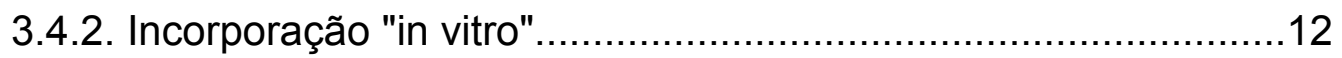

3.5. Análise por ativação neutrônica....................................................14

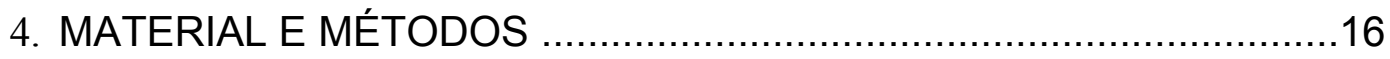

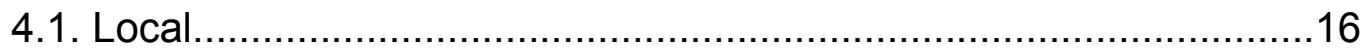

4.2. Conservação do resíduo de cervejaria...........................................16

4.2.1. Ensaio de conservação aeróbia...............................................17

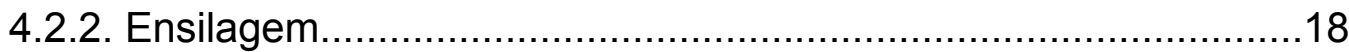

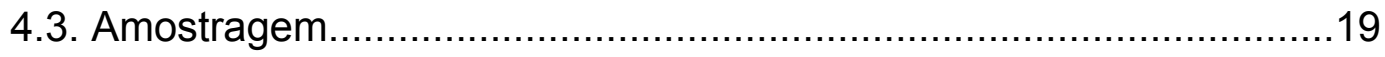

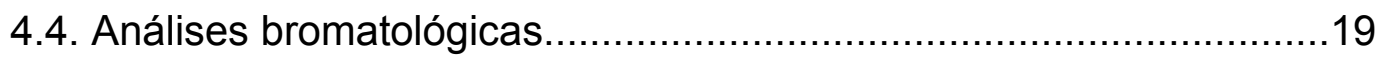

4.4.1. Determinação da matéria seca (MS) .......................................19

4.4.2. Determinação da matéria mineral (MM) ........................................20 
4.4.3. Determinação do fósforo inorgânico $(P) \ldots \ldots \ldots \ldots \ldots \ldots \ldots \ldots \ldots \ldots \ldots \ldots \ldots . . . . .20$

4.4.4. Determinação do extrato etéreo (EE) ...........................................20

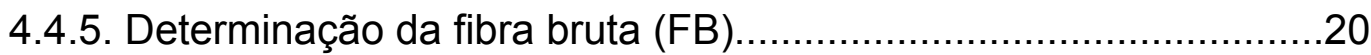

4.4.6. Determinação da fibra detergente neutro (FDN).........................21

4.4.7. Determinação da fibra detergente ácido (FDA) ...........................21

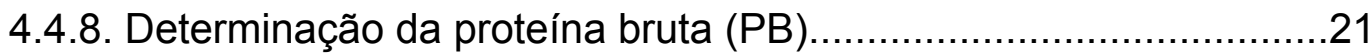

4.4.9. Determinação dos carboidratos solúveis totais.............................22

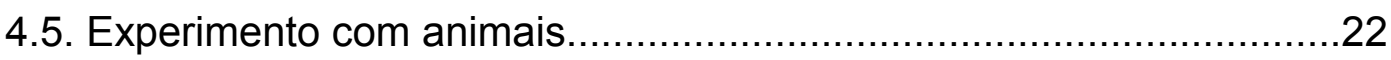

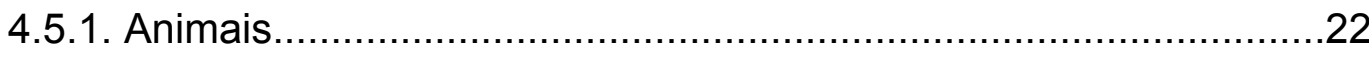

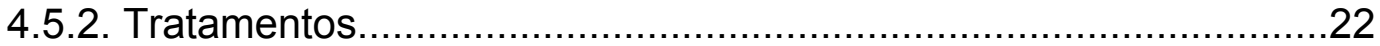

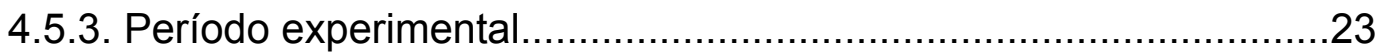

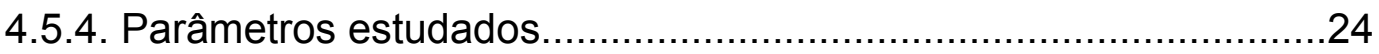

4.5.4.1. Consumo de MS e digestibilidade aparente...........................24

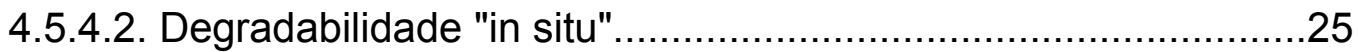

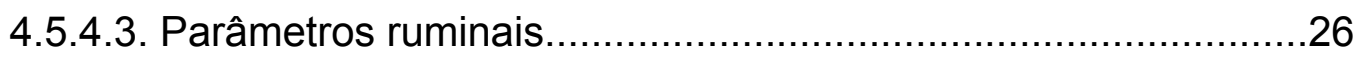

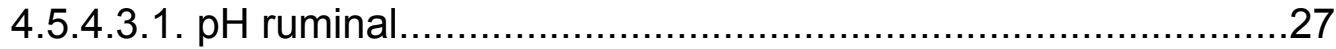

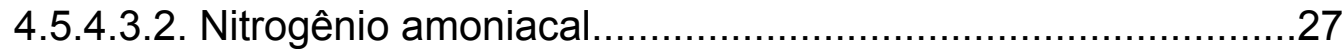

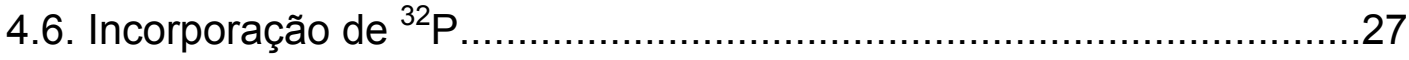

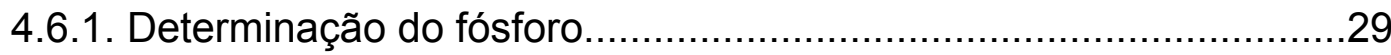

4.6.2. Cálculo da incorporação microbiana...........................................30

4.7. Análise por ativação neutrônica.......................................................31

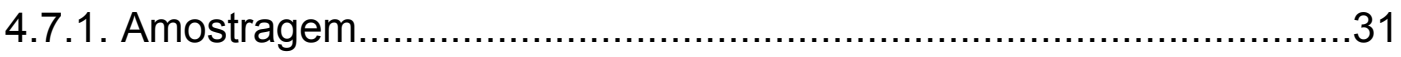

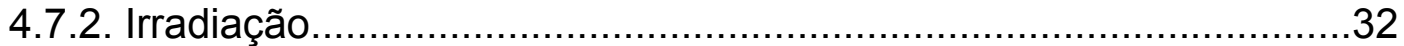

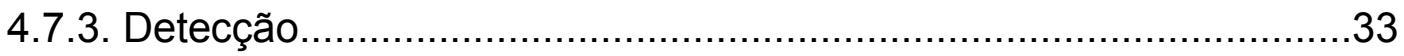

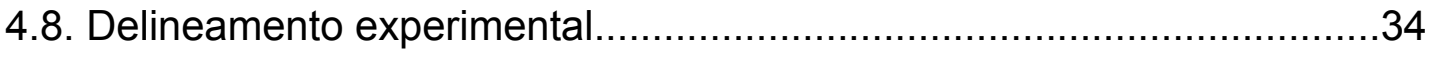

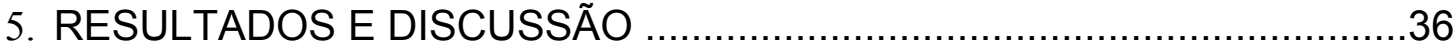

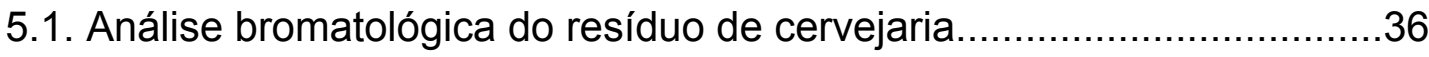

5.2. Armazenamento do resíduo de cervejaria............................................ 37

5.3. Consumo de matéria seca e digestibilidade aparente do resíduo de cervejaria ensilado 
5.4. Parâmetros ruminais................................................................ 43

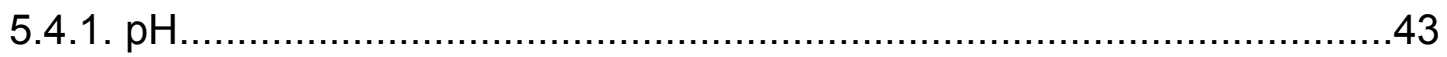

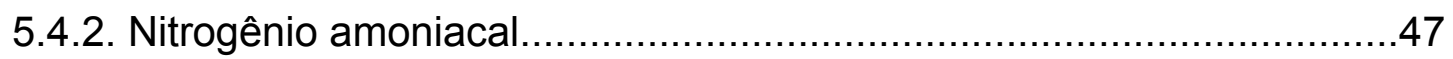

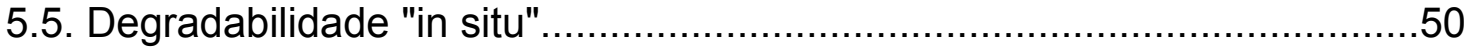

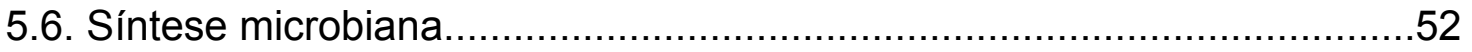

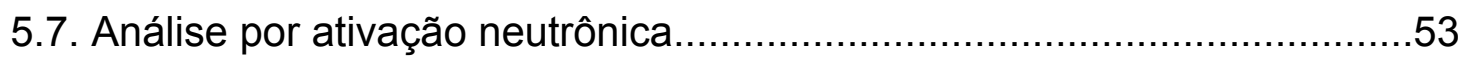

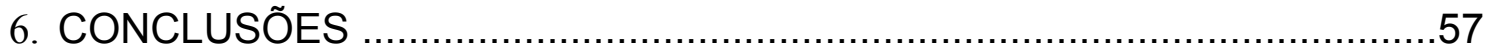

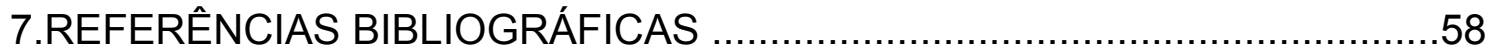




\section{LISTA DE TABELAS}

Tabela $\mathrm{n}^{\circ}$

1 Composição das dietas experimentais (em \% de MS)

2 Caracterização nutricional do resíduo de cervejaria coletado em quatro indústrias em diferentes períodos $(n=9)$.

3 Composição bromatológica das dietas experimentais contendo quantidades crescentes de resíduo de cervejaria ensilado.

4 Consumo de MS e digestibilidade aparente para ovinos alimentados com níveis crescentes do resíduo de cervejaria ensilado.

5 Concentrações médias $(\mu \mathrm{g} / \mathrm{g})$ de elementos de interesse nutricional no resíduo úmido de cervejaria, coletado em duas indústrias, em diferentes períodos, e analisados por ativação neutrônica. 


\section{LISTA DE QUADROS}

Quadro $\mathrm{n}^{\circ}$

1 Quadrados latinos com três tratamentos, três períodos e seis animais.

2 Análise de variância para 0 quadrado latino

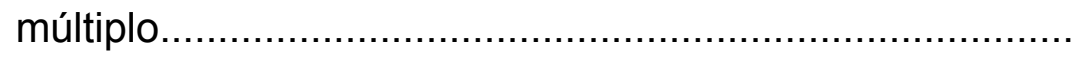




\section{LISTA DE FIGURAS}

Figura $\mathrm{n}^{\circ}$

Página

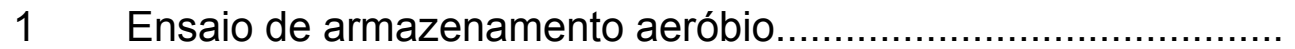

$2 \quad$ Ensilagem do resíduo de cervejaria......................................... 13

3 Variações nos teores de $\mathrm{pH}$ do rúmem de ovinos, em dietas exclusivas de feno de tifton e com a inclusão de $33 \%$ e $67 \%$ da MD na forma de silagem de resíduo de cervejaria

4 Variações das concentrações de NNH3 em mg 100ml-1 no fluído ruminal, em diferentes tempos de coleta, para os tratamentos $\mathrm{A}, \mathrm{B}$ e C. Representados respectivamente por 0, 33 e $67 \%$ da MS da dieta na forma do resíduo de cervejaria.

5 Regressão linear entre os níveis de inclusão de 0 (A), 33 (B), 67 (C) e $100 \%$ (D) da silagem do resíduo de cervejaria e a degradabilidade efetiva da MS, considerando uma taxa de passagem de $2 \% \mathrm{~h}^{-1}$ 


\section{AVALIAÇÃO DO RESÍDUO DE CERVEJARIA EM DIETAS DE RUMINANTES}

ATRAVÉS DE TÉCNICAS NUCLEARES E CORRELATAS

Sergio Lucio Salomon Cabral Filho Orientador: Prof. Dr. Adibe Luiz Abdalla

\section{RESUMO}

O estudo avaliou as características do resíduo de cervejaria úmido e ensilado durante um período de trinta dias, para isto foram utilizados seis ovinos machos, adultos, da raça Santa Inês. Os animais dotados de fístula ruminal permanente, foram distribuídos em dois quadrados latinos $3 \times 3 \mathrm{em}$ um esquema múltiplo com seis animais e três períodos experimentais. Os tratamentos adotados foram constituídos por três dietas experimentais $\mathrm{A}$, B e C onde o resíduo de cervejaria ensilado substituiu o feno de Tifton 85 (Cynodon $x$ Cynodon) nas seguintes proporções: Tratamento A - $100 \%$ de feno; Tratamento B - $67 \%$ de feno $+33 \%$ de silagem e Tratamento $C-33 \%$ de feno + $67 \%$ de silagem. As dietas experimentais foram avaliadas através das técnicas in vivo, in situ e in vitro. As avaliações in vitro foram realizadas através da técnica de incorporação microbiana com o uso de ${ }^{32} \mathrm{P}$ como marcador. Foram realizadas também análises bromatológicas e análise por ativação neutrônica do resíduo úmido coletado em diferentes indústrias e em diferentes períodos de coleta. As avaliações in vivo indicaram aumentos na digestibilidade aparente da PB de acordo com a inclusão do resíduo na dieta $(P<0,05)$, com valores de 51,6; 66,1 e 66,3 \% para as dietas A, B e C respectivamente. O tratamento $B$ apresentou maior digestibilidade da $M O(P<0,05)$ e notou-se menor digestibilidade da fração FDA $(P<0,05)$, de acordo com o aumento dos níveis do resíduo na dieta. Para as avaliações in situ foram notados maiores valores de degradabilidade da MS no rúmen de acordo com o aumento do 
resíduo na dieta $(P<0,05)$, apresentando um comportamento linear positivo de acordo com a equação: $p=0,155 n+53,866 ; R^{2}=0,922$. No estudo da incorporação do ${ }^{32} \mathrm{P}$, a síntese microbiana foi avaliada de acordo com as quantidades de nitrogênio incorporado ( $\mathrm{Ni}$ ) à massa microbiana. As dietas experimentais não apresentaram diferênças significativas $(P>0,05)$ quanto aos valores de $\mathrm{Ni}$, que ficaram em torno de 4,60; 4,62 e 5,03 mg de $\mathrm{Ni}$ incorporado por $\mathrm{g}$ de MS fermentada, para as dietas A, B e $C$ respectivamente. A ensilagem do resíduo de cervejaria úmido foi considerado uma forma eficiente de armazenagem durante o período de tempo estudado. As avaliações utilizadas mostraram que o resíduo apresentou um comportamento semelhante ao da forragem e pode ser considerado um alimento volumoso de boa qualidade, embora na avaliação in situ as taxas de desaparecimento da MS tenham sido maiores do que as do feno de Tifton. Foram notadas diminuições $(P>0,05)$ no consumo voluntário dos animais quando o resíduo foi incluído em quantidades maiores do que $33 \%$ da MS. Não foram identificadas presença de elementos tóxicos, com As, $\mathrm{Hg}$ e Cd na composição do resíduo quando analisado através da ativação neutrônica. 


\section{EVALIATION OF WET BREWER'S GRAIN IN RUMINANTS DIETS TROUGHT NUCLEARS AND CORRELATED TECHNIQUES}

Sergio Lucio Salomon Cabral Filho Adviser: Prof. Dr. Adibe Luiz Abdalla

\section{SUMMARY}

The study evaluated the wet brewer's grain silage using six male, adults Santa Inês sheep. The animals had a permanent ruminal fistula, and were distributed in two $3 \times 3$ Latin Squares in a multiple designing, with six animals and three experimental periods. The treatments was constituted by three experimental diets, $A, B$ and $C$ where the ensiled brewer's grain substituted the hay of Tifton 85 (Cynodon $x$ Cynodon) in the following ratios: A - $100 \%$ hay; B $67 \%$ of hay $+33 \%$ of silage and C - 33\% of hay $+67 \%$ of silage. The experimental diets were evaluated through the in vivo, in situ and in vitro techniques. The in vitro evaluation was the microbial incorporation technique using ${ }^{32} \mathrm{P}$ as marker. Wet brewer's grains was collected in different industries and different periods, and this material was submitted to chemical and neutron activation analysis. The in vivo evaluation indicated increases in the apparent digestibility of the $\mathrm{CP}$, when the brewer's grains were included in the diet $(P<0,05)$, the values of the digestibility were 51,$6 ; 66,1$ and $66,3 \%$ for the diets $A, B$ and $C$ respectively. Treatment $B$ showed higher digestibility of $O M(P<0,05)$ and lower digestibility of ADF fraction $(P<0,05)$, when the silage increase in the diet. For the in situ evaluation, the values of MS degradability was higher when the levels of brewer's grain increase in the diet $(P<0,05)$, the positive linear regression was obtained in accordance with the equation: $p=0,155 n+53.866$; $R^{2}=0,922$. In the study of the incorporation of the ${ }^{32} P$, the microbial synthesis 
was evaluated with the amounts of nitrogen incorporation $(\mathrm{Ni})$ in the microbial mass. Experimental diets did not present a significant difference $(P>0,05)$ of $\mathrm{Ni}$ values, that was around of 4,60; 4,62 and 5,03 $\mathrm{mg} \mathrm{Ni}$ incorporated per $\mathrm{g}$ of fermented dry matter, for the diets $A, B$ and $C$ respectively. The silage process of the wet brewer's grain was considered an efficient form of storage during the studied period. The used evaluation showed that the brewer's grains presented a similar characteristics with the forage source and it was considerate a good roughage feed, even so in the in situ evaluation the rates of DM disappearance were higher than of Tifton hay. Reductions $(P>0,05)$ in the voluntary intake of the animals were obtained when the brewer's grain was included in higher amounts than $33 \%$ of DM. Toxic elements presence, $\mathrm{As}, \mathrm{Hg}$ and $\mathrm{Cd}$ were not identified in the composition of the brewer's grain when analysed by neutron activation analysis. 


\section{INTRODUÇÃO}

A área agrícola do estado de São Paulo vem sofrendo grandes modificações nos últimos anos, com transformações importantes nas explorações agropecuárias. O grande avanço das empresas agro-industriais transformam espaços antes ocupados por pastagens em áreas de plantio, voltadas principalmente para o atendimento dos setores industriais.

O crescimento das áreas de plantio de culturas como a da cana-de-açúcar e da laranja competem com a exploração pecuária, muitas vezes porque possibilitam maiores rendimentos por área. Entretanto, o grande potencial de mercado de algumas regiões ainda torna viável a exploração de ruminantes, notado pelo recente crescimento da ovinocultura no estado.

A diminuição das áreas de pastagem e a sua estacionalidade de produção, tornam escassos alguns recursos alimentares, refletindo em elevações nos custos de produção. A grande necessidade de produção de alimentos volumosos desafia a pesquisa a buscar novas alternativas de recursos alimentares, com os objetivos de reduzir custos, facilitar o gerenciamento e aumentar a produtividade dos rebanhos.

Incorporações de novas fontes de nutrientes passam a ser comuns na exploração animal e alguns subprodutos agro-industriais como o resíduo de cervejaria, polpa de citrus, caroço de algodão e o resíduo de cana-de-açúcar, apresentam características nutricionais de interesse, além de possuírem grande disponibilidade e garantir o destino racional dos resíduos industriais, contribuindo para a preservação do meio ambiente.

O resíduo de cervejaria apresenta elevada porcentagem de componentes de parede celular, possibilitando o seu aproveitamento como alimento 
volumoso. Maiores informações sobre as características nutricionais deste resíduo, assim como seus parâmetros digestivos, são necessárias para garantir melhorias à saúde animal e uma maior qualidade dos seus produtos. 


\section{OBJETIVO}

Avaliar o resíduo de cervejaria na alimentação de ruminantes através da sua caracterização nutricional e da sua subistituição a alimentos volumosos de origem forrageira

Estudar as vantagens do armazenamento anaeróbio (silagem) do resíduo e compara-lo com as formas de armazenamento normalmente utilizadas em fazendas brasileiras (aeróbio). 


\section{REVISÃO DE LITERATURA}

\subsection{Resíduo de cervejaria}

O resíduo de cervejaria ou resíduo de cevada é um subproduto da indústria cervejeira bastante utilizado na alimentação de ruminantes. Lima (1993), calcula uma disponibilidade de aproximadamente 2 milhões de toneladas/ano deste subproduto no Brasil, onde tradicionalmente é empregado em dietas de bovinos leiteiros.

A matéria prima utilizada pelas indústrias de cerveja do Brasil é constituída por malte de cevada com a adição de uma mistura de cereais (principalmente o milho) ou maltose. O processo de fabricação do malte é chamado de maltagem e envolve o controle do umidecimento dos grãos de cevada com água e posterior germinação sobre condições controladas, com o objetivo de obter mudanças químicas e físicas com perda mínima de energia pelo processo de respiração.

A mistura do malte moído com água e a adição de seus complementos é conhecida como mosturação. O objetivo deste processo é promover a liquefação e posterior hidrólise do amido a açúcares, obtendo-se $65 \%$ de extração dos sólidos totais do malte e de 80 a $90 \%$ quando utiliza-se misturas de cereais como o arroz e o milho.

O resíduo de cervejaria pode ser descrito como uma massa resultante da aglutinação da casca com resíduos do processo de mosturação, podendo apresentar maiores concentrações de proteína e carboidratos, do que as encontradas em seus cereais de origem (Clark, 1987).

Cardoso (1982), trabalhando com o resíduo úmido no Brasil cita valores de 32,3 e $68,4 \%$ para proteína bruta (PB) e nutrientes digestíveis totais (NDT) 
respectivamente. West (1994), obteve 29,6; 6,8 e 65,5 \% para PB, extrato etéreo (EE) e fibra detergente neutro (FDN) nos EUA. Valores de 17 a $35 \%$ de PB são encontrados na literatura, mostrando certa variabilidade na composição bromatológica do resíduo de cervejaria (Lima, 1993).

Embora os maiores atrativos venham a ser os seus altos valores de proteína e amido, resultando em valores elevados de energia metabólica (EM), algumas características da fração protéica deste resíduo vem sendo estudada (Santos et al., 1984; Armetano, et al., 1986; Valladares Filho et al., 1990).

Dados obtidos de experimentos com vacas em lactação, ovelhas e carneiros sugerem que 50 \% ou mais da proteína bruta, escape da degradação microbiana do rúmen e passe para o intestino delgado (Clark, 1987). Santos et al. (1984), medindo fermentação ruminal, o fluxo e a absorção de aminoácidos no intestino de vacas leiteiras, compararam farelo de soja, farelo de glúten de milho, resíduo de cervejaria e resíduo de destilaria e concluíram que dietas contendo farinha de glúten, resíduo de cervejaria e resíduo de destilaria fornecem maiores quantidades de aminoácidos para o intestino do que o farelo de soja. Esta insolubilidade de parte da fração protéica de alguns alimentos é conhecida na nutrição de ruminantes como "bypass".

Quanto ao conteúdo de minerais, o NRC de ovinos (1978), apresenta valores de 0,54; 0,29 e 0,09 para fósforo, cálcio e potássio, respectivamente. Os baixos conteúdos de potássio foram encontrados por Hoffman \& Armentano (1988), que aconselham uma suplementação deste elemento quando o resíduo substituir alimentos ricos neste mineral. Considerações sobre elevados teores de selênio também são encontradas na literatura, onde o resíduo é indicado na suplementação deste elemento para rebanhos com problemas de reprodução em regiões que apresentam deficiências (Crinckenberger \& Johnson, 1982).

O resíduo de cervejaria é classificado pelas indústrias como um concentrado de médio valor protéico e não um substituto forrageiro. Entretanto, Harris (1991) indica que a adição do resíduo em dietas de vacas em produção 
contribui para o atendimento dos requerimentos de fibra, podendo ser incluído em taxas de 15 a $20 \%$ da matéria seca (MS) total da dieta.

\subsubsection{Fatores limitantes}

Os baixos valores de MS encontrados no resíduo de cervejaria são apontados como a maior limitação na utilização deste subproduto na forma úmida. Valores entre 20 e $30 \%$ de MS são encontrados na literatura (Clark, 1987; Lima, 1993; Phipps et al., 1995).

A elevada quantidade de água no resíduo úmido pode resultar em outros fatores limitantes como a dificuldade no transporte a longa distância e dificuldades no armazenamento. Muitos autores limitam a utilização deste subproduto a determinadas distâncias das indústrias. Nas condições dos E.U.A., pesquisadores acreditam que o resíduo só é econômico até um raio de aproximadamente $100 \mathrm{~km}$ das indústrias (Eastridge, 1991; Chandler, 1997).

A conservação deste material em propriedades rurais também é considerada uma limitação. Allen (1975), cita os fungos e as leveduras como os principais microrganismos responsáveis pela degradação do resíduo em condições de aerobiose. A rápida biodegradação foi observada por Stern \& Ziemer (1993), que sugerem menores períodos de armazenamento; estudos em condições de aerobiose aconselham períodos de no máximo 10 dias (Johnson, 1987).

No Brasil, o resíduo de cervejaria é comercializado na forma úmida e normalmente armazenado em condições aeróbias, em períodos de 20 a 30 dias. A prática adotada na maioria das fazendas é a adição do sal comum $(\mathrm{NaCl})$ na tentativa de diminuir o ataque de microrganismos.

A desidratação parcial do resíduo é prática comum em muitos países e pode minimizar estes problemas. Rogers et al. (1986) alimentaram novilhos com silagem de milho e uma suplementação com o resíduo na forma úmida ou desidratada, mostrando diferenças nutricionais associadas a alterações na utilização da proteína entre os tratamentos. 
O decréscimo na utilização da proteína do resíduo desidratado em relação à forma úmida, é resultado dos efeitos das elevadas temperaturas empregadas no processo de secagem, já descritas para outros alimentos submetidos aos mesmos tratamentos (Goering \& Waldo, 1974).

Diminuições nas porcentagens de nitrogênio solúveis para o resíduo desidratado foram encontradas por Rogers et al. (1986), que atribuíram estas alterações ao tratamento térmico. Os autores utilizaram o nitrogênio da fibra detergente ácido (NIDA) como um indicador das possíveis alterações protéicas causadas pela exposição do resíduo a temperaturas elevadas.

Alguns resultados mostram apenas pequenas reduções na degradabilidade protéica do resíduo desidratado e atribuem estas diferenças à intensidade do tratamento pelo calor (Alawa et al., 1988).

\subsubsection{Desempenho animal}

Devido ao seu alto valor nutricional e à sua disponibilidade quase constante ao longo do ano, o resíduo de cervejaria sempre atraiu muito os produtores de leite. Principalmente como fonte protéica para vacas em início de lactação (Stern \& Ziemer, 1993).

A boa aceitabilidade do resíduo pelos animais, levaram a investigações de possíveis aumentos no consumo de MS e consequentemente na produção de leite e nas porcentagens de gordura e proteína do leite.

Trabalhos com substituições de silagem de gramíneas pelo resíduo de cervejaria como principal volumoso para vacas leiteiras, foram conduzidos por Phipps et al. (1995) na Inglaterra. Os valores de energia e proteína do resíduo foram maiores do que os encontrados na silagem e substituições de $33 \%$ da MS resultaram em aumento no valor nutritivo da dieta. Não houve efeito significativo no consumo de matéria seca, entretanto obteve-se aumento da produção de leite.

Decréscimos na porcentagem de gordura do leite também foram citados em alguns trabalhos, atribuídos principalmente ao alto conteúdo de gorduras 
insaturadas do resíduo. Elevadas quantidades de gordura insaturada, associada a uma diminuição na digestão da porção fibra são apontadas por Miller et al. (1970) como responsáveis pelas diminuições nos valores da gordura do leite.

Hoffman \& Armetano (1988), não encontraram diferenças significativas entre a produção de leite de vacas alimentadas com o resíduo úmido ou seco ou com farelo de soja, nos Estados Unidos. Sugerem que a escolha do suplemento deve ser baseada no custo e na sua disponibilidade.

Na produção de carne, o resíduo vem sendo utilizado principalmente como fonte energética e protéica em dietas para animais em crescimento e terminação.

Valores de 2,01 a 2,55 e de 1,20 a 1,51 kcal de EM/g de MS foram encontrados por Preston et al. (1973), nos Estados Unidos, para mantença e ganho respectivamente. Neste trabalho, novilhos em crescimento receberam dietas à base de milho ou suplementadas com até $50 \%$ do resíduo desidratado e apresentaram maiores coberturas de gordura e aumento do peso de carcaça para os tratamentos contendo o resíduo.

Aumentos dos níveis de células vermelhas, hemoglobina, hematócrito e colesterol foram determinados no sangue de ovinos alimentados com o resíduo de cervejaria em substituição ao feno como volumoso. Aumentos no ganho de peso em animais que receberam este resíduo em comparação com o feno e outros subprodutos foram descritos por Fekry et al. (1989), em condições subtropicais secas, na África.

\subsection{Processo de ensilagem}

A fermentação de determinadas bactérias sobre os carboidratos solúveis de um alimento pode ser descrita como o processo de ensilagem. A atividade de fermentação destes microrganismos na ausência do oxigênio resulta em 
compostos capazes de conservar um determinado alimento ao longo do tempo (Peixoto, 1988).

Alguns subprodutos industriais foram conservados na forma de silagem, principalmente os resíduos de indústrias de conservas e de sucos, como tomate, uva (Lima et al., 1986) e laranja (Sampaio et al., 1984). Parâmetros como o $\mathrm{pH}$, quantidades de nitrogênio na forma volátil $\left(\mathrm{N}-\mathrm{NH}_{3}\right)$ e determinações dos ácidos orgânicos são empregados nas avaliações da qualidade da silagem. Silveira (1975), mostrou que o nitrogênio na forma volátil pode funcionar como um bom indicador da degradação de compostos protéicos.

As medidas de $\mathrm{pH}$ são atualmente muito utilizadas nas determinações de qualidade do material ensilado, mas não como um valor único, podendo ser dependente da porcentagem de matéria seca e do teor de açúcar.

Valores de umidade em torno de 70 \% são indicados na literatura como recomendáveis para o processo (Peixoto, 1988). Na ensilagem de grãos são considerados ideais, valores de matéria seca entre 25 e $35 \%$.

O desenvolvimento de microrganismos indesejáveis como o Clostridium foi identificado em silagens com elevado teor de umidade. Segundo McDonald et al. (1991), estas bactérias são muito sensíveis à oferta de água, necessitando de muita umidade para o seu desenvolvimento. $\mathrm{O} p \mathrm{pH}$ ideal para $\mathrm{o}$ seu crescimento situa-se entre 7,0 a 7,4 podendo desenvolver-se até em pH 4,0 em culturas com excesso de umidade.

\subsection{Fibra de subproduto em dietas de ruminantes}

A fração fibra pode ser definida como um agrupamento de carboidratos para fins nutricionais. Van Soest (1975), divide os carboidratos das forragens como: (1) em geral disponíveis, (2) parcialmente disponíveis e (3) em geral indisponíveis. Fibra, em um conceito mais moderno, pode ser definida como a parede celular dos vegetais, podendo variar nos conteúdos de hemicelulose, celulose e lignina, assim como nas ligações existentes entre estes componentes (Mertens, 1998). 
Estudos mais recentes mostram que a divisão nutricional dos carbohidratos estruturais sugerida por Van Soest (1975), pode ser determinada através da porção fibra detergente neutro (FDN). Uma fração de digestibilidade lenta ou indigestível, de fundamental importância para as funções ruminais, formada pelas frações hemicelulose, celulose e lignina e atualmente muito utilizada, podendo representar melhor os valores biológicos de digestibilidade e energia das forragens (Mertens, 1998).

Muitos subprodutos apresentam altos valores de FDN na sua composição bromatológica. Esta porção vem sendo classificada por alguns autores como "fibra de origem não forrageira", podendo apresentar diferentes comportamentos quando substituem a fibra das forragens (Grant, 1997; Jeffrey, 1997). Variações na digestão do FDN de subprodutos em relação às forragens podem resultar em mudanças físicas na digestão e alterações no desempenho animal. Jeffrey (1997), analisando dados de taxa de passagem e medidas de gravidade específica de subprodutos em vacas de alta produção de leite, encontrou menores valores das taxa de passagem destes subprodutos em relação as forragens.

As possíveis alterações físicas na digestão da fibra de subprodutos são descritas através de processos digestivos como tempo de ruminação, atividade de mastigação e consistência do material ruminal (Mertens, 1998). Estas alterações podem ser identificadas através de parâmetros como o consumo de MS, alterações do $\mathrm{pH}$ ruminal, mudanças na relação entre acetato e propionato no líquido ruminal e alterações nos teores de gordura do leite (Davis, 1970; Clark, 1980).

A digestibilidade da fibra do resíduo de cervejaria, do caroço de algodão e da polpa de beterraba foi avaliada por Torrent (1993), nos Estados Unidos. O trabalho foi feito com ovinos através das técnicas in vivo e in situ. $\mathrm{O}$ autor utilizou o feno de alfafa como referência para digestão das porções fibrosas encontrando valores de digestibilidade total no trato variando entre $33 \%$ no caroço de algodão, até 78 \% na polpa de beterraba. O feno de alfafa e a polpa 
de beterraba apresentaram maiores taxas de desaparecimento da FDN no rúmen: 0,124 e $0,116 h^{-1}$, respectivamente, onde valores de 0,035 e $0,043 h^{-1}$, foram encontrados para o resíduo de cervejaria e para o caroço de algodão, respectivamente.

\subsection{Métodos de avaliação dos alimentos}

Algumas metodologias foram propostas buscando a caracterização do valor nutritivo dos alimentos para os ruminantes. A partir do melhor conhecimento dos processos digestivos destes animais, muitas técnicas novas apareceram e algumas avaliações consagradas pela sua utilização passaram a ter pouca participação ou em alguns casos deixaram de ser utilizadas.

Os nutrientes digestíveis totais (NDT) é um dos mais antigos métodos de avaliação de alimento e baseia-se em coeficientes de digestão para cada fração bromatológica (Maynard et al., 1984). Devido às variações dos coeficientes na estimativa do NDT, muitas vezes o valor de um alimento não é corretamente determinado. Alguns aspectos da fermentação ruminal como o tempo em que o alimento permanece no rúmen, a solubilidade deste alimento no fluído ruminal, assim como a facilidade de colonização deste alimento por microrganismos ruminais e a absorção de seus nutrientes no trato, são variações que devem ser levadas em conta para a correta avaliação de um alimento para ruminantes.

O método convencional denominado de digestibilidade aparente, considera $\mathrm{o}$ alimento ingerido e os nutrientes recuperados nas fezes, calculando-se a digestibilidade por diferença, podendo ser estudada a digestibilidade da matéria seca e dos diferentes nutrientes.

\subsubsection{Degradabilidade "in situ"}

A técnica "in situ" proposta por Ørskov \& McDonald (1977), é fundamentada nas taxas de degradação dos alimentos suspenso em sacolas de nylon no rúmen por vários períodos de tempo. O modelo proposto por estes autores é representado pela função exponencial: 


$$
p=a+b\left(1-e^{-c t}\right)
$$

onde a letra $\boldsymbol{p}$ representa a degradação de determinado nutriente em função do tempo $\boldsymbol{t},(\boldsymbol{a}+\boldsymbol{b})$ indica a degradabilidade potencial e $\boldsymbol{c}$ a taxa de degradação. $\mathrm{O}$ modelo fornece a estimativa da degradabilidade efetiva do alimento, levando em conta as taxas de passagens ("outflow rate") de 2,5 a 8,0 \% $\mathrm{h}^{-1}$.

Esta metodologia foi amplamente aplicada no sistema inglês de avaliação dos alimentos, A.F.R.C. (1993), que além das estimativa das quantidades de PB e EM, pode determinar os conteúdos de proteína efetivamente degradada no rúmen e de proteína digestível não degradada no rúmen.

\subsubsection{Incorporação "in vitro" do ${ }^{32} \mathrm{P}$ e síntese microbiana}

Algumas técnicas foram propostas com o intuito de determinar as quantidades de matéria orgânica (MO) dos alimentos fermentadas pelos microrganismos do rúmen, elementos marcadores destes organismos como o 2.6-ácido diaminopimelínico , ou o radioenxôfre $\left({ }^{35} \mathrm{~S}\right.$ ) (Hutton et al., 1971; Beever et al., 1974), foram utilizados com esta finalidade. Entretanto as possíveis incorporações de peptídeos e aminoácidos extracelulares, assim como as dificuldades laboratoriais de métodos utilizando $0{ }^{35} \mathrm{~S}$, tornaram necessária a utilização de outros elementos químicos como marcadores.

A adoção do fósforo radioativo $\left({ }^{32} \mathrm{P}\right)$ como elemento marcador da atividade microbiana, baseou-se no princípio que os compostos fosforilados como os nucleotídeos não conseguem penetrar nas células microbianas, entretanto os ácidos nucléicos fosforilados representam a maioria dos ácidos nucléicos microbianos, tornando aceitável que todo o $\mathrm{P}$ microbiano é derivado de compostos fosforilados extracelulares (Van Nevel \& Demeyer, 1977).

$\mathrm{O}$ uso de radioisótopos tem mostrado resultados satisfatórios em pesquisas relacionadas com a utilização de $\mathrm{P}$ pelos organismos do rúmen. 
Através da coleta de amostra de líquido de rúmen pode-se medir a taxa de incorporação do ${ }^{32} \mathrm{P}$ in vitro, avaliando desta maneira a atividade microbiana (Vitti et al. 1988). O método baseia-se na relação entre a incorporação do $P$ na matéria microbiana e a síntese de proteína, na utilização de amônia ou produção de ácidos graxos voláteis em períodos de incubações curtos, usando ${ }^{32} \mathrm{P}$ como marcador (Van Nevel \& Demeyer, 1977).

Segundo Van Nevel \& Demeyer (1977), a atividade específica do ${ }^{32} \mathrm{P}$ extracelular $\left(A E_{e}\right)$, em dpm/mg, é dada pela relação entre a contagem da porção sobrenadante, ou extracelular (em desintegrações por minuto, dpme e a quantidade de $P$ extracelular total $\left(P_{e}\right)$ na amostra encaminhada para a contagem, em mg, ou seja,

$$
A E_{e}=\frac{d p m_{e}}{P_{e}}
$$

A quantidade de ${ }^{32} \mathrm{P}$ incorporada à massa microbiana $\left(\mathrm{P}_{\mathrm{i}}\right)$, em $\mathrm{mg}$, é dada pela relação entre as contagens no material precipitado $\left(\mathrm{dpm}_{\mathrm{i}}\right)$ e a atividade específica extracelular $\left(\mathrm{AE}_{\mathrm{e}}\right)$ :

$$
P i=\frac{d p m_{i}}{A E_{e}}
$$

Van Nevel \& Demeyer (1977) chegaram a um valor de 8,37 $\pm 0,75$ para a relação N:P na massa microbiana dos animais e substratos por eles estudados, possibilitando a utilização deste valor na multiplicação da quantidade de ${ }^{32} \mathrm{P}$ incorporado, para o cálculo do total de nitrogênio incorporado na massa microbiana $\left(\mathrm{N}_{\mathrm{i}}\right)$. 


\subsection{Análise por ativação neutrônica}

A análise por ativação neutrônica é um método instrumental de determinação elementar, desenvolvido por indução e posterior detecção de radioatividade, baseando-se no conhecimento e na especificidade de algumas constantes físicas (DeSoet et al., 1972).

A indução é realizada a partir do bombardeamento das amostras com nêutrons de energia variável, através do emprego de reatores nucleares ou geradores de nêutrons. Os nuclídeos estáveis presente nas amostras recebem esta energia, resultando em instabilidade nuclear e radioatividade.

$A$ atividade produzida de um dado radionuclídeo $\left(A_{0}\right)$ depende do número de átomos do nuclídeo alvo presente $(\mathrm{N})$, da intensidade do fluxo de nêutrons $(\phi)$, do tempo de irradiação $\left(\mathrm{t}_{\mathrm{i}}\right)$, da meia vida do radionuclídeo formado $(\mathrm{T})$ e da probabilidade de ocorrência de reação e da seção de choque $(\sigma)$, conforme a equação:

$$
A_{0}=N \cdot \phi \cdot \sigma \cdot\left(1-e^{-0,693-t i / T}\right)
$$

A grande maioria dos radioisótopos formados após a ativação das amostras por um determinado fluxo de nêutrons é formada por emissores gama. Portanto, para a análise por ativação neutrônica, são normalmente empregados os detectores por cintilação sólida $\mathrm{NaI}(\mathrm{TI})$ e o semicondutor de $\mathrm{Ge}(\mathrm{Li})$ acoplados a um analisador multicanal, impressora de dados e registrador gráfico, sendo que o detector semicondutor apresenta uma alta resolução em relação ao cintilador sólido, podendo separar raios $\gamma$ de energia bem próxima (Simabuco \& Nascimento Filho, 1984).

Estudos mais recentes de avaliação de subprodutos na alimentação de ruminantes (Silva Filho et al., 1999) utilizaram a técnica de ativação neutrônica para a detecção de elementos químicos de importância nutricional e toxicológica (As, $\mathrm{Ca}, \mathrm{Co}, \mathrm{Cr}, \mathrm{Fe}, \mathrm{Hg}, \mathrm{K}, \mathrm{Mo}, \mathrm{Na}, \mathrm{Sb}$ e $\mathrm{Zn}$ ). Este estudo avaliou 
alimentos como farelo de algodão, arroz, canola, soja e trigo, farinhas de peixe, pena, carne e penas + vísceras, cascas de algodão, arroz, laranja e bagaço de tomate. A técnica de ativação neutrônica mostrou-se eficiente na análise qualitativa e quantitativa destes elementos, indicando níveis aceitáveis dos minerais analisados nos alimentos estudados e assegurando a utilização destes em dietas de ruminantes quanto a presença de elementos tóxicos como o arsênio e o mercúrio. 


\section{MATERIAL E MÉTODOS}

\subsection{Local}

As análises laboratoriais e o experimento com os animais foram realizados no Laboratório de Nutrição Animal (LANA) do Centro de Energia Nuclear na Agricultura, Universidade de São Paulo; no período de agosto de 1998 a abril de 1999.

Para as análises de caracterização nutricional, foram utilizados resíduos úmidos, coletados em quatro indústrias da região, identificadas como indústrias $1,2,3$ e 4 . Deste material foram realizadas principalmente as análises bromatológicas. Nas avaliações de conservação, nos trabalhos com os animais e nas análises por ativação neutrônica, foram utilizados resíduos coletados apenas nas indústrias 3 e 4 .

\subsection{Conservação do resíduo de cervejaria}

Em uma primeira fase foram avaliadas formas de armazenamento do resíduo de cervejaria em condições experimentais, com objetivo de estabelecer a maneira mais adequada para a sua utilização no experimento com os animais. Inicialmente avaliaram-se algumas formas de armazenamento aeróbio de emprego comum em propriedades rurais. Após este estudo a forma de armazenamento anaeróbio (ensilagem) foi testada.

Para o trabalho com os animais, optou-se pela conservação anaeróbia, na forma de silagem, devido principalmente às inferiores condições de conservação apresentadas no ensaio de armazenamento aeróbio. 


\subsubsection{Ensaio de conservação aeróbia}

O resíduo foi coletado e armazenado em tambores plásticos durante 30 dias nas formas úmida e seca ao sol. O material armazenado na forma úmida foi dividido em quatro tratamentos: tratamento 1 (in natura, resíduo puro sem armazenamento), tratamento 2 (resíduo puro armazenado no tambor em condições aeróbicas), tratamento 3 (tratamento $2+2 \%$ de sal como cobertura) e tratamento 4 (tratamento $2+10 \%$ de sal como cobertura). Parte deste material foi submetido a uma secagem ao sol no dia em que chegou da indústria até aproximadamente $20 \%$ de umidade e posteriormente armazenado em sacos de ráfia, caracterizando o tratamento 5 .

Nos tratamentos 1, 2, 3 e 4 cada parcela foi representada por $20 \mathrm{Kg}$ do resíduo úmido, acondicionado em tambores plásticos de $50 \mathrm{I}$, com perfurações na base e coletores para a drenagem do excesso de efluentes (Figura1). Nos tratamentos 3 e 4, sobre o resíduo de cervejaria foram adicionados 400 gramas (tratamento 3) e $2 \mathrm{~kg}$ (tratamento 4) de sal comum.

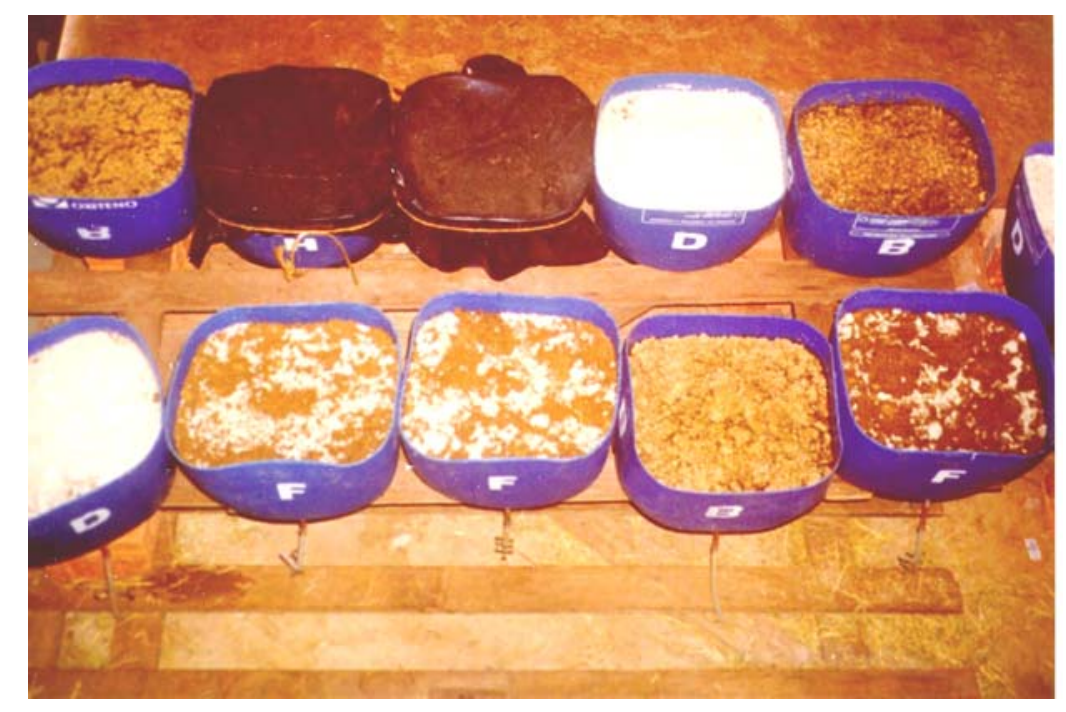

Figura 1 - Ensaio de armazenamento aeróbio

Os tratamentos foram avaliados de acordo com Allen et al. (1975); os quais propuseram uma avaliação visual da intensidade de crescimento de 
fungos, onde uma escala de 0 a 5 indica os níveis de colonização destes organismos.

\subsubsection{Ensilagem}

Para a ensilagem foram utilizados 5 silos experimentais, feitos com tambores plásticos tipo "bombas" de 200 I de capacidade, onde $1300 \mathrm{~kg}$ do resíduo úmido, coletados na indústria 4 e instalados no LANA (Figura 2). 0 material sofreu compactação, sendo acondicionado até o máximo de capacidade dos tambores. Os silos foram então tampados resultando em um total de $1244 \mathrm{~kg}$ armazenados.

Com o intuito de promover a drenagem do excesso de umidade dos silos (efluente), os tambores foram mantidos na posição horizontal com uma ligeira inclinação na parte inferior destes, sendo suas tampas levemente afrouxadas permitindo a drenagem. A medida em que os silos eram abertos, permaneciana posição vertical e após a retirada das porções diárias oferecidas aos animais, eram protegidos com saco plástico, diminuindo o contato com o ar. Na retirada da silagem foram descartados os $5 \mathrm{~cm}$ iniciais, considerados como perdas.

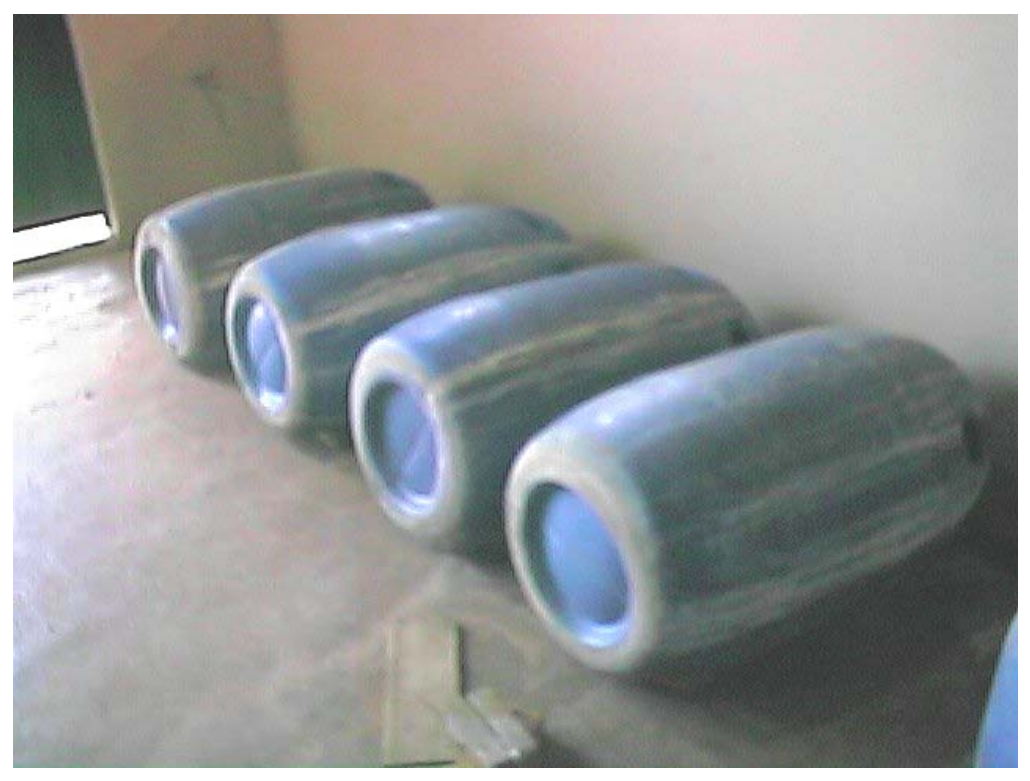

Figura 2 - Ensilagem do resíduo de cervejaria 


\subsection{Amostragem}

Para o ensaio de armazenamento aeróbio, amostrou-se em quatro diferentes pontos dos tambores após os 30 dias. A amostragem foi realizada com o auxílio de um trado de caneco. Após a retirada do trado, coletou-se apenas a porção sub-superfical desprezando-se as partes relativas a camada superficial. As amostras foram colocadas em bandejas de alumínio, submetidas a análise visual de crescimento de fungos (Allen et al., 1975), pesadas e secas em estufa $\left(60^{\circ} \mathrm{C}\right)$ até peso constante. Estas amostras foram armazenadas a temperatura ambiente na ausência de oxigênio até serem encaminhadas para as análises laboratoriais.

No resíduo ensilado as amostras também foram retiradas com trado, em vários pontos, nos 5 tambores. As amostragens foram realizadas após 30, $40 \mathrm{e}$ 60 dias de armazenamento. Este material foi submetido aos mesmos procedimentos descritos para as amostras do ensaio de armazenamento aeróbio.

\subsection{Análises bromatológicas}

Todas as amostras de resíduo utilizadas no estudo foram submetidas a determinações da matéria seca (MS), matéria mineral (MM), fósforo inorgânico $(P)$, extrato etéreo $(E E)$, fibra bruta $(F B)$, fibra detergente neutro (FDN), fibra detergente ácido (FDA) e proteína bruta (PB); e seguiram as metodologias utilizadas como rotina no LANA segundo a literatura pertinente (Van Soest, 1964; Van Soest \& Wine, 1967; CUNIFF, 1995)

\subsubsection{Determinação da matéria seca (MS)}

Para esta determinação, aproximadamente $1 \mathrm{~g}$ das amostras foram pesadas em cadinhos de porcelana, levadas para estufa a temperatura de 
$100^{\circ} \mathrm{C}$ até peso constante. Em seguida as amostras foram novamente pesadas, obtendo-se a quantidade de matéria seca através da diferença entre os pesos.

\subsubsection{Determinação da matéria mineral (MM)}

$\mathrm{Na}$ determinação da matéria mineral, os cadinhos provenientes da determinação da MS foram encaminhados para a mufla $\left(550^{\circ} \mathrm{C}\right)$, onde permaneceram durante 4 horas. Após o resfriamento os cadinhos contendo as cinzas foram pesados determinando-se as quantidades de MM.

\subsubsection{Determinação do fósforo inorgânico $(P)$}

As determinações de fósforo foram realizadas de acordo com a metodologia do vanadato-molibidato, descrita por Sarruge \& Haag (1974). As cinzas resultantes das determinações da $\mathrm{MM}$, sofreram digestão clorídrica $(\mathrm{HCl}$ 2:1) e foram filtradas até a obtenção de um extrato livre de impurezas sólidas. Após a filtragem adicionou-se as soluções dos reagentes molibidato de amônio (5\%) e vanadato de amônio $(0,25 \%)$, determinando-se os teores de fósforo através de fotocolorimetria.

\subsubsection{Determinação do extrato etéreo (EE)}

O extrato etéreo foi obtido através da extração de aproximadamente $1 \mathrm{~g}$ da amostra, durante 4 horas, com éter etílico. Toda a fração solúvel da amostra foi recebida em um becker de peso determinado e as quantidades de extrato etéreo calculadas através da diferença entre o peso final e original dos beckers.

\subsubsection{Determinação da fibra bruta (FB)}

Após a extração do extrato etéreo as amostras sofreram digestão a quente em solução ácida fraca $\left(\mathrm{H}_{2} \mathrm{SO}_{4} 1,25 \%\right)$ por 30 minutos, o resíduo desta digestão sofreu nova digestão em solução álcali fraca ( $\mathrm{NaOH} 1,25 \%)$ durante o mesmo tempo, sendo o resíduo final filtrado e levado para estufa a $100^{\circ} \mathrm{C}$. As amostras secas foram pesadas e levadas para mufla a $550^{\circ} \mathrm{C}$, durante 4 horas. 
As quantidades de fibra bruta das amostras foram obtidas através da diferença entre as pesagens.

\subsubsection{Determinação da fibra detergente neutro (FDN)}

Para a determinação dos conteúdos de FDN, aproximadamente $1 \mathrm{~g}$ de amostra sofreu digestão a quente durante 60 minutos, por uma solução detergente neutro contendo $30 \mathrm{~g}$ de lauril sulfato de sódio, $10 \mathrm{ml}$ de etileno glicol, $18,61 \mathrm{~g}$ de sódio EDTA dihidratado, $6,81 \mathrm{~g}$ de borato de sódio decahidratado e $4,55 \mathrm{~g}$ de fosfato de sódio anidro por litro. Os resíduos foram filtrados em cadinhos Gooch e secos em estufa $100^{\circ} \mathrm{C}$. A diferença entre pesos forneceu as quantidades de FDN presente nas amostras.

\subsubsection{Determinação da fibra detergente ácido (FDA)}

$\mathrm{Na}$ determinação desta fração os procedimentos seguidos diferiram das determinações de FDN, apenas pela solução detergente ácido utilizada na digestão das amostras. A solução foi formada por $28,8 \mathrm{ml}$ de ácido sulfúrico concentrado e $20 \mathrm{~g}$ de cetiltrimetilbrometo de amônio por litro. As amostras sofreram digestão durante 60 minutos e após filtradas e secas foram pesadas e calculadas as quantidades de fibra detergente ácido.

\subsubsection{Determinação da proteína bruta (PB)}

Foi empregado o método de micro-Kjeldahl, onde $100 \mathrm{mg}$ da amostra sofreram digestão com ácido sulfúrico concentrado na presença de catalisadores (sulfato de potássio ou de sódio). $\mathrm{Na}$ fase de destilação, o material digerido foi submetido à reação com uma solução de hidróxido de sódio $(\mathrm{NaOH})$ concentrado para a liberação de amônia. O produto da destilação foi recebido em um recipiente com solução contendo ácido bórico (20 g de $\left.\mathrm{H}_{3} \mathrm{BO}_{3} / \mathrm{l}\right)$ e os indicadores vermelho de metila e verde de bromocresol. Os conteúdos de nitrogênio das amostras foram determinados através da titulação com ácido sulfúrico $0,1 \mathrm{~N}$ e as quantidades de PB obtidas a partir da 
multiplicação dos teores de nitrogênio total $(\mathrm{Nt})$ por um fator 6,25 (considerando que as proteínas possuem em média $16 \%$ de nitrogênio).

\subsubsection{Determinações dos carboidratos solúveis totais}

A extração foi realizada em $1 \mathrm{~g}$ de amostra, adicionando-se $100 \mathrm{ml}$ de água fervente e aquecendo em banho-maria por 30 minutos. A solução final foi diluída até que apresentasse concentração de 10 a $100 \mu \mathrm{g}$ de carboidratos em $2 \mathrm{ml}$ de solução. Dois mililitros desta solução foram pipetados para tubo de ensaio, adicionando-se $1 \mathrm{ml}$ de fenol (5\%) e $5 \mathrm{ml}$ de $\mathrm{H}_{2} \mathrm{SO}_{4}$ concentrado, deixando os tubos em repouso durante 10 minutos. Após a reação os tubos foram levados para leitura em fotocolorímetro e os resultados colocados em uma curva padrão feita a partir da glicose.

\subsection{Experimento com animais}

\subsubsection{Animais}

Foram utilizados seis carneiros adultos, da raça Santa Inês, castrados e dotados de fístulas ruminais. Os animais iniciaram o experimento com peso médio de 73,03 $\pm 3,24 \mathrm{Kg}$ sendo anteriormente submetidos a exames coproparasitológicos, através da contagem de ovos nas fezes pela técnica de McMaster (Whitlock, 1948).

Foi administrado vermífugo injetável (Ripercol) e complexo vitamínico (ADE THOR, Laboratório Tortuga) antes do início da fase experimental e realizadas coletas de sangue para análise de hematócrito e hemoglobina.

\subsubsection{Tratamentos}

Os tratamentos adotados buscaram a substituição da matéria seca de uma forragem tropical pelo resíduo de cervejaria ensilado e foram representados na forma de três dietas experimentais; conforme mostra a Tabela 
1. A forragem utilizada foi o feno de Tifton 85 (Cynodon $x$ Cynodon) disponível no mercado.

Tabela 1. Composição das dietas experimentais (em \% MS).

\begin{tabular}{l|cc}
\hline Tratamentos & Feno de tifton 85 & Silagem do resíduo de cervejaria. \\
\hline Tratamento A & $100 \%$ & $0 \%$ \\
Tratamento B & $67 \%$ & $33 \%$ \\
Tratamento C & $33 \%$ & $67 \%$ \\
\hline
\end{tabular}

Além das dietas experimentais, os animais receberam mistura mineral comercial (30 g/animal/dia). As dietas foram oferecidas "ad libitum" duas vezes ao dia, às 8:30 e às 16:30h em quantidades que resultassem em um mínimo de 10 a $20 \%$ de sobra. A água foi oferecida a vontade durante todo o período experimental.

\subsubsection{Período experimental}

O período experimental teve a duração de 63 dias, formados por 3 subperíodos de 21 dias. Os subperíodos foram divididos em três fases, onde na primeira foi realizado o estudo do consumo voluntário, na segunda fase os animais permaneceram em gaiolas de metabolismo para o estudo da digestibilidade aparente e na terceira foram mantidos em três baias, cada uma com dois animais, recebendo as mesmas dietas experimentais, para o estudo da degradabilidade in situ. Após o início do período experimental, os animais passavam por três dias de adaptação as dietas, cinco dias de coletas do oferecido e do refugado para o estudo de consumo e sete dias de coletas de oferecido, sobras e fezes, para os estudos da digestibilidade aparente. Posteriormente permaneciam em jejum de $24 \mathrm{~h}$ após o qual, eram realizadas as coletas de conteúdo ruminal para a incorporação do radiofósforo $\left({ }^{32} \mathrm{P}\right)$. As 
coletas de líquido do rúmen para as determinações de $\mathrm{pH}$ e nitrogênio amoniacal foram realizadas após o último dia do ensaio de digestibilidade, com os animais ainda nas gaiolas.

\subsubsection{Parâmetros estudados}

\subsubsection{Consumo de MS e digestibilidade aparente}

Para as determinações do consumo de MS, as sobras foram coletadas e pesadas diariamente, durante cinco dias de cada subperíodo. As sobras eram recolhidas pela manhã, antes do fornecimento da primeira refeição e após sua pesagem eram retiradas amostras de aproximadamente $10 \%$ do peso total para as determinações de MS. O total oferecido, foi pesado diariamente para cada animal de acordo com as quantidades refugadas no dia anterior. Os dois alimentos foram pesados separadamente e só misturados no cocho. Amostras de aproximadamente $1 \mathrm{~kg}$ de feno e da silagem, foram coletadas de dois em dois dias para as determinações da MS dos alimentos oferecidos. A secagem foi realizada em estufa $\left(60^{\circ} \mathrm{C}\right)$ até peso constante.

Para o estudo da digestibilidade aparente, foram coletadas amostras do oferecido, das sobras e do total das fezes, diariamente. As coletas do oferecido realizaram-se da mesma maneira que as descritas para a fase de consumo e, após a secagem, as amostras foram armazenadas a uma temperatura aproximada de $5^{\circ} \mathrm{C}$ para posteriores análises. As sobras foram coletadas duas vezes ao dia, antes do oferecimento das dietas, e as fezes, diariamente, logo após a primeira alimentação do dia.

Das amostras totais de sobras e de fezes, foram retiradas sub-amostras de $10 \%$ do peso total coletado, e levadas para a secagem $\left(60^{\circ} \mathrm{C}\right)$ até peso constante. A partir daí, foram determinadas suas quantidades de MS, sendo estas armazenadas a $5^{\circ} \mathrm{C}$ para as análises bromatológicas. Para o oferecido foram realizadas quatro coletas durante os sete dias, aproximadamente $500 \mathrm{~g}$ 
do feno e da silagem, coletados separadamente, secos e armazenados conforme descrito para as sobras e fezes.

Após o término do período experimental, estas amostras resfriadas foram submetidas a determinações de MS, PB, FDN, FDA e lignina (LIG) conforme A.O.A.C (1995) e Van Soest (1967). Para isto, misturou-se os 7 dias de coletas de fezes e sobras de cada animal ("pool"), resultando em um total de 18 amostras compostas. Para o oferecido, a mistura foi realizada entre as três coletas de cada período, resultando em 6 amostras finais.

\subsubsection{Degradabilidade in situ}

Durante o estudo da degradabilidade in situ os animais permaneceram em baias, dois a dois, recebendo as mesmas dietas que eram oferecidas durante $o$ estudo de metabolismo.

A metodologia empregada foi a descrita por Ørskov e McDonald (1980), onde aproximadamente $3 \mathrm{~g}$ dos alimentos estudados (feno e silagem) e das dietas experimentais ( $A, B$ e $C$ ), após passarem por peneiras de $2 \mathrm{~mm}$, em moinho do tipo Willey, foram colocados em sacos de nylon padronizados, com dimensões de $85 \times 115 \mathrm{~mm}$ e incubados, suspensos no rúmen dos animais, para a estimativa da cinética da digestão.

Os tempos de incubação foram $0,3,8,16,24,48,72$ e 96 horas. Os sacos eram umedecidos antes da incubação e receptados em água com gelo na retirada, para a interrupção da atividade microbiana.

Para a dieta $A$, os animais receberam dois sacos para cada horário, contendo apenas feno. Nas dietas B e C, os animais receberam três sacos para cada horário, um com feno, o outro com a silagem e o terceiro com os dois alimentos, na mesma proporção da dieta oferecida. Sendo assim, os animais receberam no rúmen apenas os alimentos presentes na sua dieta, com a 
finalidade de obter-se uma máxima atuação dos microrganismos nos substratos incubados.

No final de cada tempo de incubação, lavou-se os sacos em água corrente apenas para a retirada das impurezas externas e, então, foram congelados. No final de todo o período de incubação (96h), os sacos foram lavados em água, por 30 minutos em uma lavadora automática. Todos os sacos foram secos em estufa $\left(60^{\circ} \mathrm{C}\right)$ até peso constante. Após a secagem, os sacos foram novamente pesados para as determinações de MS.

Os valores obtidos para as taxas de desaparecimento da MS nos diferentes tempos de incubação, assim como as perdas de MS por lavagem ("washing loss"), foram processados em um "software" distribuído pelo Rowett Research Institute, Aberdeen, Escócia, o qual foi desenvolvido para o modelo de Ørskov e McDonald (1979). O programa forneceu a estimativa da degradabilidade efetiva dos alimentos incubados, o "lag time", a solubilidade em água $(A)$ e as quantidades de material insolúvel, porém fermentáveis, definida como $B=(a+b)-A$.

\subsubsection{Parâmetros ruminais}

As amostras de líquido ruminal foram retiradas com auxílio de uma sonda, adaptada a uma seringa plástica de $50 \mathrm{ml}$. Os animais permaneceram em gaiolas metabólicas e as coletas foram realizadas uma vez em cada período

experimental, nos horários de $0,1,1^{1 / 2}, 2,3,4,5,6,9^{1 / 2}, 14$ e 22 hs após o fornecimento das dietas experimentais. As coletas foram realizadas no último dia das medidas de consumo voluntário, antes do início do estudo da digestibilidade aparente, nos três períodos experimentais. $O$ líquido coletado foi transferido para copos de plástico descartáveis, homogeneizado e acondicionados nos frascos de vidro em quantidades de aproximadamente $20 \mathrm{ml}$. Os frascos com as amostras foram congelados, sendo que, nas amostras 
destinadas a análise de $\mathrm{N}-\mathrm{NH}_{3}$, adicionou-se ácido sulfúrico concentrado para a paralisação da atividade microbiana.

\subsubsection{1. $\mathrm{pH}$ ruminal}

$\mathrm{O} \mathrm{pH}$ do rúmen foi analisado imediatamente após a coleta do líquido. Amostras de aproximadamente $20 \mathrm{ml}$ foram transferidas para os frascos de vidro e o pH medido através de um potenciômetro da marca Orion, modelo $701 \mathrm{~A}$. As medições foram realizadas uma vez em cada período, utilizando-se os horários de coleta sugeridos no trabalho de McAllan et. al (1994), descritos no item 3.5.3.

\subsection{Nitrogênio amoniacal}

Após as medições do $\mathrm{pH}$, as amostras receberam $2 \mathrm{ml}$ de ácido sulfúrico concentrado (P.A.) e foram estocadas a $-20^{\circ} \mathrm{C}$ para subsequente análise do $\mathrm{N}$ $\mathrm{NH}_{3}$. Para a análise do nitrogênio amoniacal no líquido ruminal, foram seguidos os passos descritos por Preston (1995). A amônia foi separada do líquido ruminal através de destilação a quente, recebida em solução de ácido bórico e determinada através da titulação com um ácido padrão. Após o descongelamento, o fluído ruminal foi centrifugado por 15 minutos (3000 rpm) e $5 \mathrm{ml}$ do sobrenadante transferido para os tubos de destilação. Na destilação, foi utilizado $10 \mathrm{ml}$ de solução de tetraborato de sódio para o aumento do $\mathrm{pH}$ e volatilização da amônia, que foi recebida em solução de ácido bórico (20 \%) até um volume de 30 a $40 \mathrm{ml}$. As amostras finais foram tituladas com $\mathrm{HCl} 0,1 \mathrm{~N}$.

\subsection{Incorporação $d o^{32} P$}

As amostragens para a incorporação do ${ }^{32} \mathrm{P}$ e determinações da síntese microbiana realizaram-se no final de cada período experimental. Após o término 
da fase de digestibilidade in situ, os animais permaneceram em jejum de $24 \mathrm{~h}$ para que o líquido ruminal fosse o mais livre possível de resíduos da dieta.

Os substratos estudados foram as três dietas experimentais. Pesou-se os dois alimentos separadamente misturando-os de maneira a obter as mesmas proporções das dietas experimentais. Amostras contendo aproximadamente $1 \mathrm{~g}$ de MS foram colocadas em tubos plásticos $(50 \mathrm{ml})$, próprios para centrífuga Sorval, utilizando-se três tubos (repetições) para cada tratamento ( $A, B$ e $C$ ).

A coleta dos inóculos foi realizada pela manhã, após o período de jejum. As amostras de líquido ruminal foram coletadas diretamente no rúmen através de sondas adaptadas a seringas de $50 \mathrm{ml}$. Foram colhidos e mantidos em anaerobiose aproximadamente $120 \mathrm{ml}$ de líquido para cada tratamento (mistura de dois animais), sendo identificados como substratos A, B e C de acordo com o tratamento recebido pelo animal.

Aos tubos com os substratos, adicionou-se $4 \mathrm{ml}$ de saliva artificial $(25 \mathrm{~g}$ de glucose e $3 \mathrm{~g}$ de bicarbonato de sódio por litro), $16 \mathrm{ml}$ do líquido ruminal (filtrado com duas gases) e $25 \mu$ de solução do radiofósforo, correspondendo a 0,1 $\mu \mathrm{Ci}$ (3700 Bq ) de ${ }^{32} \mathrm{P}$ para cada tubo.

Para cada tratamento estudado, três tubos receberam os substratos, os outros dois receberam apenas o inóculo, a saliva artificial e a solução de radiofósforo. Estes tubos foram chamados de branco e serviram para descontar os valores de incorporação do ${ }^{32} \mathrm{P}$ na ausência dos substratos.

Todos os tubos foram levados à incubadora a $39^{\circ} \mathrm{C}$ com saturação de gás carbono, permanecendo durante um período de $8 \mathrm{~h}$, sendo que um tubo com substrato e um dos tubos brancos tiveram a atividade microbiana paralisada através da adição de $1 \mathrm{ml}$ de $\mathrm{H}_{2} \mathrm{SO}_{4} 18 \mathrm{~N}$ antes de serem incubados. Após o período de incubação os outros tubos também receberam o $\mathrm{H}_{2} \mathrm{SO}_{4}$.

Os tubos foram levados para centrifugação por $10 \mathrm{~min}$ a $10.000 \mathrm{rpm}$ sendo o sobrenadante separado, do qual $1 \mathrm{ml}$ foi pipetado para tubos do tipo 
Cerenkov sendo o volume elevado para $20 \mathrm{ml}$ com água destilada. Este material foi encaminhado imediatamente para contagem em cintilador líquido (Packard mod. 1600 TR).

O precipitado foi lavado por três vezes com solução salina, sendo centrifugado após cada lavagem e o sobrenadante desprezado. No término das lavagens o precipitado foi novamente suspendido a $20 \mathrm{ml}$ com água destilada, 5 $\mathrm{ml}$ foram colocados em cadinhos para as determinações da MS e MM. O precipitado foi então submetido a digestão a quente com $\mathrm{H}_{2} \mathrm{SO}_{4}$ 1: 1 durante $1: 30 \mathrm{~h}$.

Após a digestão os conteúdos foram transferidos para tubos do tipo Cerenkov, sendo novamente suspendidos para um volume de $20 \mathrm{ml}$ com água destilada. Os tubos foram então encaminhados para contagem, seguindo os mesmos procedimentos da porção sobrenadante.

\subsubsection{Determinação do fósforo}

A análise do fósforo inorgânico foi realizada apenas com a porção sobrenadante, seguindo a metodologia citada por Fiske \& Subbarow (1925). Para a extração da proteína verdadeira, adicionou-se o ácido tricloroacético a $10 \%$. Após extração da proteína, $2,5 \mathrm{ml}$ da amostra foram transferidos para tubos de ensaio, adicionou-se então $0,5 \mathrm{ml}$ do reagente molibidato e $0,2 \mathrm{ml}$ da solução de aminonafitolsulfônico e completou-se o volume para $5 \mathrm{ml}$ com água destilada. As leituras foram feitas em colorímetro (Vital Scientifc, modelo VITALAB 10) contra água destilada e comparadas a um padrão de leitura conhecida. 


\subsubsection{Cálculos da incorporação microbiana}

Inicialmente foi calculada a atividade específica extracelular $\left(\mathrm{AE}_{\mathrm{e}}\right)$. Esta variável foi obtida através dos resultados de contagem da porção extracelular das amostras ( $\left.A_{\text {eamt }}\right)$ e da atividade do padrão $\left(A_{p}\right)$, solução contendo apenas o radiofósforo. Para a determinação da $A E_{e}$, os resultados das contagens das amostras e do padrão foram ainda divididos pelas quantidades de fósforo determinadas no sobrenadante $(P)$ conforme a expressão:

$$
A E_{e}=\frac{\frac{A_{e-a m t}}{A_{p}}}{P}
$$

A partir da determinação da $A E_{e}$, pode ser calculada as quantidades de fósforo incorporada $\left(P_{i}\right)$ na porção precipitada das amostras. Para isto foram realizadas as contagens do precipitado, obtendo-se a atividade específica do precipitado $\left(\mathrm{A}_{\mathrm{i}-\mathrm{amt}}\right)$, nesta ocasião também foi determinada a atividade específica do padrão $\left(A_{p}\right)$ de maneira similar ao sobrenadante. Para a determinação das quantidades de fósforo incorporado, ainda foram considerados os valores de volumes totais $\left(V_{t}\right)$ e o volume das amostras $\left(V_{a m t}\right)$, conforme a equação:

$$
P_{i}=\frac{\frac{A_{i-a m t}}{A_{p}}}{A E_{e}} x \frac{V_{t}}{V_{a m t}}
$$


Calculada as quantidades do $P_{i}$ na porção precipitada pode-se estimar as quantidades de microrganismos incorporados para cada substrato em estudo ( $\mathrm{A}, \mathrm{B}$ e $\mathrm{C}$ ). Os resultados de $\mathrm{P}_{\mathrm{i}}$ estão diretamente ligados a atividade microbiana obtida em cada tratamento, a atividade microbiana foi então expressa nas quantidades de nitrogênio incorporada $\left(\mathrm{N}_{\mathrm{i}}\right)$ na massa microbiana. Para a obtenção das quantidades de $N_{i}$ na massa microbiana, foi utilizada a relação entre fósforo e nitrogênio encontrada por VanNevel \& Demeyer (1977) nos diferentes componentes celulares:

$$
N_{i}=P_{i} x 8,37
$$

\subsection{Análise por ativação neutrônica}

Durante o período de julho a outubro de 1999, foram realizadas as análises por ativação neutrônica, junto ao Laboratório de Radioisótopos do CENA e ao Instituto de Pesquisas Energéticas e Nucleares da Universidade de São Paulo (IPEN/USP).

\subsubsection{Amostragem}

As amostras foram coletadas em duas indústrias cervejeiras da região, (indústria 3 e 4). As amostras foram coletadas em duas épocas diferentes na indústria 3 e em três na indústria 4, resultando em 5 amostras finais. Foram coletadas amostras de aproximadamente $5 \mathrm{~kg}$ em cada coleta, sendo estas retiradas logo após a filtragem do mosto cervejeiro, diretamente dos filtros.

As amostras foram secas a $60^{\circ} \mathrm{C}$ até peso constante e moídas em moinho do tipo Willey, utilizando peneiras com furos de $1 \mathrm{~mm}$ de diâmetro. Esta primeira fase foi realizada no Laboratório de Nutrição Animal (LANA) e após o preparo 
das amostras, estas foram enviadas para o Laboratório de Radioisótopos do CENA (LRI).

O preparo das amostras no LRI iniciou-se com novas determinações de umidade das amostras, feita em estufa a $60^{\circ} \mathrm{C}$, até peso constante. Após as determinações de umidade, as amostras foram encaminhadas para encapsulação.

\subsubsection{Irradiação}

As amostras foram acondicionadas em cápsulas cilíndricas de polietileno de alta pureza, próprias para a análise por ativação neutrônica. Foram utilizadas cápsulas de $18 \mathrm{~mm}$ de altura e $9 \mathrm{~mm}$ de diâmetro. Inicialmente, pesou-se as cápsulas vazias, e posteriormente, com as amostras, com repetição ou em duplicata. As amostras e os padrões foram então depositados nas cápsulas e levemente compactados, até aproximadamente dois terços do volume total das cápsulas. Em seguida as 16 cápsulas foram pesadas novamente, resultando em massa aproximada de $250 \mathrm{mg}$ das amostras e dos padrões em cada cápsula.

Os padrões utilizados foram o "Apple Leaves", "IEA/V-10 Hay" e o "Tomato Leaves", certificados pela Agência Internacional de Energia Atômica. Foi adotado o procedimento relativo de análise, com resultados obtidos através de comparação de amostras com os padrões.

Um fio composto por liga de níquel e cromo, 21,3\% de $\mathrm{Cr}$ e $77,1 \%$ de $\mathrm{Ni}$, com $10 \mathrm{mg}$ de massa, foi colocado entre as cápsulas para a monitoração do fluxo a que cada amostra foi submetida. As cápsulas foram embrulhadas uma a uma em folhas de alumínio e dispostas em camadas de três, em recipientes de alumínio apropriados para a irradiação com nêutrons, denominados "coelhos".

Os "coelhos" contendo as amostras foram enviados ao IPEN, em São Paulo, dia 05/07/99, onde foram submetidos durante 8 horas a um fluxo térmico da ordem de $9 \times 10^{12} \mathrm{n} . \mathrm{cm}^{2}$.s no reator IAE-R1. 
Após a irradiação, as amostras permaneceram no IPEN por dois dias, tempo para o decaimento de nuclídeos de meias-vidas mais curtas, diminuindo sensivelmente a atividade global e facilitando o manuseio. $O$ material foi então retirado e transportado para o CENA, onde as cápsulas foram desembrulhadas, separando-se os monitores de fluxo. Cada cápsula foi centralizada em frascos plásticos de $15 \mathrm{ml}$, preenchendo-se os espaços restantes com isopor. Os fios de níquel cromo foram colocados individualmente em frascos semelhantes.

\subsubsection{Detecção}

Para a detecção da radioatividade induzida, empregou-se detector de germânio hiperpuro, modelo GEM-50220 de fabricação EG\&G ORTEC, posicionado no centro de blindagem cilíndrica com paredes de $15 \mathrm{~cm}$ de ferro e $15 \mathrm{~cm}$ de chumbo. Todo o equipamento eletrônico também teve procedência EG\&G ORTEC, "Bias Supply" modelo 459, amplificador 572 e uma placa acumuladora de dados MCB- $916^{\mathrm{A}}$, com conversor análogo-digital, inserida em um microcomputador $486 \mathrm{DX} 2$. Na aquisição as contagens foram realizadas com 4096 canais, abrangendo emissores gama na faixa de 100 a $1800 \mathrm{keV}$, com monitoração através do programa GAMMA VISION 5.0 - EG\&G ORTEC.

A detecção foi feita apenas para os radionuclídeos com meias-vidas superiores a 12 horas, pois o reator utilizado localiza-se a $160 \mathrm{~km}$ do LRI.

As detecções foram realizadas em quatro corridas para as amostras e os padrões. Para os monitores de fluxo foram realizadas apenas duas corridas. As distâncias entre fonte radioativa e detector foi sempre a menor possível, desde que evitassem tempos mortos superiores a $10 \%$. Para as amostras e padrões, procurou-se um tempo máximo ideal, que permitisse a contagem de todos em um período limitado pelo decaimento dos nuclídeos envolvidos na análise. Os espectros foram armazenados em disquetes para posterior interpretação. 


\subsection{Delineamento experimental}

No ensaio com animais, o delineamento experimental adotado foi o quadrado latino múltiplo com três animais e três períodos, os seis animais formaram dois quadrados $3 \times 3$ que desenvolveram-se simultaneamente, cada um deles com os três tratamentos propostos.

Os animais foram separados nos quadrados de acordo com o peso vivo dividindo-os em leves e pesados, conforme o Quadro 2. Os tratamentos foram sorteados em cada quadrado e o quadro de análise da variância determinado conforme o Quadro 3. As análises foram realizadas através do programa Statistical Analysis System (SAS, 1991).

Quadro 1. Quadrados latinos com três tratamentos, três períodos e seis animais.

\begin{tabular}{|c|c|c|c|c|c|c|}
\hline \multirow{4}{*}{ Período } & \multicolumn{6}{|c|}{ Quadrado latino (LS) } \\
\hline & \multirow{2}{*}{\multicolumn{3}{|c|}{$\begin{array}{r}\text { LS } 01 \\
67,3 \mathrm{~kg}\end{array}$}} & \multirow{2}{*}{\multicolumn{3}{|c|}{$\begin{array}{c}\text { LS } 02 \\
78,3 \mathrm{~kg}\end{array}$}} \\
\hline & & & & & & \\
\hline & G2 & G3 & G6 & G1 & G4 & G5 \\
\hline I & A & B & C & $A$ & B & C \\
\hline II & B & $\mathrm{C}$ & $A$ & B & $\mathrm{C}$ & $A$ \\
\hline III & $\mathrm{C}$ & $A$ & B & $\mathrm{C}$ & $A$ & B \\
\hline
\end{tabular}

Segundo Mead et al., 1993. 
Quadro 2. Análise de variância para o quadrado latino múltiplo.

\begin{tabular}{cc}
\hline Causas de variação & Graus de liberdade \\
\hline Período & 2 \\
Animal & 5 \\
Tratamento & 2 \\
Erro & 8 \\
\hline Total & 17 \\
\hline
\end{tabular}

No ensaio de degradabilidade in situ os tratamentos foram representados pelas diferentes proporções dos alimentos incubados nos sacos de nylon. Neste ensaio foram avaliados cinco tratamentos representados pelos níveis crescentes de silagem $(0,33,67$ e 100\%), em substituição ao feno de tifton. Os tratamentos foram aplicados nos seis animais, nos três período experimentais e devido a natureza dos dados, optou-se pela análise por regressão linear, onde os níveis do resíduo foram considerados como uma variável independente e a degradabilidade efetiva como variável dependente. As relações entre as duas varáveis estudadas foram representadas na forma de uma regressão linear.

A análise estatística da incorporação microbiana do ${ }^{32} \mathrm{P}$, foi feita utilizandose o delineamento experimental dos blocos casualizados no tempo, onde os blocos foram representados pelos três períodos experimentais, com três tratamentos, dietas A, B e C, que formaram os substratos utilizados para a incorporação. Cada tratamento continha duas repetições, que foram representados pelos dois animais doadores de inóculo. 


\section{RESULTADOS E DISCUSSÃO}

\subsection{Análise bromatológica do resíduo de cervejaria}

Ao longo do estudo foram realizadas análises bromatológicas e químicas de resíduos de cervejaria de diferentes indústrias, os resultados estão representados na Tabela 2 .

Tabela 2. Caracterização nutricional do resíduo de cervejaria coletado em quatro indústrias em diferentes períodos $(n=9)$.

\begin{tabular}{|c|c|c|c|c|}
\hline Composição & Média & Desvio padrão & Míminimo & Máximo \\
\hline Matéria Seca ${ }^{1}$ & 938,57 & 15,8 & 916,6 & 977,5 \\
\hline Proteína Bruta ${ }^{1}$ & 248,60 & 42,2 & 200,2 & 342,1 \\
\hline Extrato Etéreo ${ }^{1}$ & 88,15 & 19,3 & 55,3 & 124,1 \\
\hline Fibra Bruta ${ }^{1}$ & 135,86 & 23,3 & 111,9 & 158,3 \\
\hline $\mathrm{FDN}^{1}$ & 599,55 & 51,5 & 526,7 & 687,5 \\
\hline $\mathrm{FDA}^{1}$ & 239,21 & 42,5 & 144,1 & 295,0 \\
\hline $\mathrm{Pi}^{1}$ & 6,88 & 2,7 & 4,1 & 9,5 \\
\hline $\mathrm{Ca}^{1}$ & 2,37 & 0,4 & 2,1 & 2,7 \\
\hline $\mathrm{Cu}^{2}$ & 15,23 & 5,1 & 9,6 & 19,5 \\
\hline Energia Bruta ${ }^{3}$ & 4481 & 353,6 & 4231 & 4732 \\
\hline Carbohidratos $^{1}$ & 4,27 & 2,2 & 2,6 & 6,8 \\
\hline Fenóis $^{1}$ & 3,94 & 1,4 & 2,5 & 5,3 \\
\hline
\end{tabular}


Os resultados mostraram grandes variações entre os resíduos coletados. Grande parte desta variação deve-se a estratégia de fabricação em cada indústria, podendo ser modificado de acordo com a necessidade de fabricação ou com a época do ano. A adição do milho, arroz, ou da própria maltose, podem ser responsáveis por estas variações.

O teor médio de proteína bruta para o resíduo coletado nas diferentes indústrias e analisados neste trabalho apresentaram valores de $248,6 \mathrm{~g} . \mathrm{kg}^{-1}$ com variação de 200,2 a $342,1 \mathrm{~g} . \mathrm{kg}^{-1}$. Para a fibra detergente neutro, os resultados foram de 527 a $687 \mathrm{~g} . \mathrm{kg}^{-1}$ caracterizando os elevados teores de celulose e hemicelulose presentes no subproduto.

Valores de PB encontrados na literatura e revisados por Lima (1993), variaram de 170 a $350 \mathrm{~g} \mathrm{~kg}^{-1}$. Para a FDN, Stern \& Zeimer (1992) reportaram valores de 580 a $650 \mathrm{~g} \mathrm{~kg}^{-1}$, enquanto o NRC (1989) indica valores de $460 \mathrm{~g} \mathrm{~kg}$ ${ }^{-1}$. Os resultados de FDN analisados neste estudo estão mais próximos dos encontrados por Stern \& Zimer (1992).

Os valores de cobre $(\mathrm{Cu})$ indicados na Tabela 2, confirmam as altas concentrações deste elemento no resíduo. A toxidez do $\mathrm{Cu}$ em ruminantes esta restrita aos ovinos. Conrad et al. (1985) determinou valores acima de 10 ppm, como tóxico para os ovinos em regiões tropicais. As quantidades médias deste elemento nos resíduos estudados ficaram em torno de $15 \pm 5,1 \mathrm{ppm}$, levando a suspeita de possíveis problemas de intoxicação nos animais.

No ensaio in vivo, o resíduo utilizado para a ensilagem apresentou teores de 9,6 ppm de $\mathrm{Cu}$. Os animais foram alimentados durante 60 dias com a silagem do resíduo e não demonstraram sinais de intoxicação por $\mathrm{Cu}$.

\subsection{Armazenamento do resíduo de cervejaria}

A conservação do resíduo úmido em condições de aerobiose não demonstrou resultados satisfatórios. Dos tratamentos propostos para o estudo do armazenamento aeróbio apenas as parcelas que receberam a pré- 
secagem ao sol (tratamento 5), não apresentaram sinais nítidos de biodegradação, como alterações no odor, na estrutura física e nos teores de umidade.

Os tratamentos 2 e 3 receberam valor 5 de acordo com a escala proposta por Allen (1975), pois apresentaram visíveis crescimento de fungos, sinais de deterioração e odor ofensivo.

O tratamento 4 apresentou menores sinais de descoloração e odor. A adição do cloreto de sódio mostrou ser eficiente na preservação do material quanto ao crescimento de fungos e na diminuição da incidência de larvas de moscas. Porém foram notados sinais de quebras na superfície no material armazenado nestas condições, resultado em diminuições nos teores de MS, este tratamento recebeu o valor 3 na escala de Allen et al. (1975).

A secagem ao sol (tratamento 5) evitou o crescimento de fungos, não apresentando alterações que indicassem deterioração, podendo ser classificado como valor 0 da escala de Allen et al. (1975).

O armazenamento do resíduo em condições anaeróbia, ou seja na forma de silagem, demonstrou bons resultados quanto à biodegradação. O material armazenado durante 30 dias apresentou um bom aspecto, com odor agradável e ausência de sinais que demonstrasse o crescimento de fungos. O resíduo ensilado não apresentou grandes variações nos teores de matéria seca e demonstrou quedas nos valores de $\mathrm{pH}$, que apresentou variações de 5,2 no material in natura, e 4,0 no material armazenado por 30 dias.

A drenagem dos silos experimentais foi fundamental para garantir um bom armazenamento do resíduo. Os baixos teores de MS deste material geraram grandes quantidades de efluente durante o tempo de armazenagem. Este efluente mostrou ser prejudicial para a fermentação e foi responsável pelas perdas obtidas nas partes inferiores dos tambores (silos).

Os valores de $\mathrm{pH}$ obtidos após os 30 dias de armazenamento, mostraramse satisfatórios quando comparado aos valores sugeridos pela literatura, embora seria de interesse uma avaliação microbiológica mais completa, 
principalmente quanto a presença de crescimento bacteriano do tipo Clostridium. A aceitação da silagem pelos animais foi considerada uma avaliação de valor, principalmente na sua utilização em dietas de ovinos, animais que apresentam importantes características de seletividade dos alimentos. Trabalhando com silagem do resíduo de suco de maracujá, Korndörfer (1998) encontrou valores de 4,1; 4,2 e 4,2 para o pH em 0, 56 e 112 dias de armazenamento respectivamente. Phipps et al. (1995), obteve $\mathrm{pH} 4,0$ para a silagem do resíduo de cervejaria úmido e caracterizou este alimento com um bom substituto dos volumosos forrageiros em dietas de vacas em lactação.

\subsection{Consumo de MS e digestibilidade aparente do resíduo de cervejaria ensilado}

A composição bromatológica das dietas experimentas estão determinadas na Tabela 3.

Tabela 3.Composição bromatológica das dietas experimentais contento quantidades crescentes de resíduo de cervejaria ensilado

\begin{tabular}{lccc}
\hline \multirow{2}{*}{ Parâmetros } & \multicolumn{3}{c}{ Dietas } \\
\cline { 2 - 4 } & $\mathrm{A}(0 \%)$ & $\mathrm{B}(33 \%)$ & $\mathrm{C}(67 \%)$ \\
\hline $\mathrm{MS}^{1}$ & & & 350,2 \\
$\mathrm{~PB}^{1}$ & 895,5 & 687,4 & 196,3 \\
$\mathrm{EE}^{1}$ & 125,8 & 160,5 & 91,1 \\
FDN $^{1}$ & 24,4 & 63,8 & 676,6 \\
FDA $^{1}$ & 639,1 & 684,9 & 350,2 \\
\hline
\end{tabular}

1 - resultados expressos em g.kg ${ }^{-1}$.

As dietas experimentais propostas apresentaram níveis crescentes de PB e EE. Os resultados de consumo das dietas experimentais (Tabela 4), apresentaram diminuições significativas $(P>0.05)$ quando os animais 
receberam a dieta $\mathrm{C}$, com $67 \%$ da MS na forma de silagem do resíduo de cervejaria.

Tabela 4.Consumo de MS e digestibilidade aparente para ovinos alimentados com níveis crescentes do resíduo de cervejaria ensilado

\begin{tabular}{lcccc}
\hline & \multicolumn{3}{c}{ Dietas } & \multirow{2}{*}{ Erro padrão } \\
\cline { 2 - 4 } & $\mathrm{A}$ & $\mathrm{B}$ & $\mathrm{C}$ & \\
\hline Consumo $^{1}$ & $1,09^{\mathrm{a}}$ & $1,13^{\mathrm{a}}$ & $0,74^{\mathrm{b}}$ & 0,07 \\
Digest. Aparente $^{2}$ & & & & \\
MS & $47,76^{\mathrm{a}}$ & $52,80^{\mathrm{a}}$ & $44,68^{\mathrm{a}}$ & 3,03 \\
MO & $51,10^{\mathrm{ab}}$ & $55,10^{\mathrm{a}}$ & $47,24^{\mathrm{b}}$ & 1,88 \\
PB & $51,62^{\mathrm{b}}$ & $66,11^{\mathrm{a}}$ & $66,34^{\mathrm{a}}$ & 1,43 \\
FDN & $54,68^{\mathrm{a}}$ & $54,87^{\mathrm{a}}$ & $49,07^{\mathrm{a}}$ & 2,06 \\
FDA & $52,43^{\mathrm{a}}$ & $52,20^{\mathrm{a}}$ & $41,18^{\mathrm{b}}$ & 1,87 \\
\hline
\end{tabular}

a, b - Valores nas linhas com diferentes letras sobrescritas são diferentes

segundo o teste de Tukey ao nível de $5 \%$ de probabilidade. 1- kg MS.dia, 2- \%.

Os principais motivos para a diminuição do consumo encontrados podem ter sido resultado das características do resíduo ensilado, ou das menores quantidades de MS nas dietas que receberam altos níveis deste alimento.

A característica de seletividade dos ovinos pareceu também contribuir para os menores valores no consumo quando a silagem do resíduo foi fornecida em maiores quantidades da MS da dieta (tratamento $\mathrm{C}$ ). Os animais que receberam este tratamento apresentaram nas sobras, maiores quantidades da silagem quando comparado ao feno de tifton, podendo ser notado através da avaliação das quantidades de PB encontrada nas sobras, que apresentaram valores de $129,04 \pm 4,41 ; 152,70 \pm 6,05$ e $217,06 \pm 4,86 \mathrm{~g} \mathrm{Kg}^{-1}$, para os tratamentos $\mathrm{A}, \mathrm{B}$ e $C$ respectivamente.

Batajoo \& Shaver (1994), obtiveram efeito linear negativo para o consumo de MS de vacas em lactação, a medida em que diminuíram as quantidades de fibra do resíduo de cervejaria desidratado, em relação a fibra de origem forrageira. Atribuíram este comportamento as maiores quantidades de FDN nas dietas com menores quantidades de fibra de origem do subproduto. 
Phipps et al. (1995), também encontraram aumentos do consumo trabalhando com o resíduo ensilado em dietas de vacas em lactação, concluindo que o resíduo ensilado pode ser utilizado como um alimento volumoso de boa qualidade. A comparação entre dietas exclusivas de milho ou com substituições de 25 e 50 \% da MS pelo resíduo desidratado na alimentação de novilhos de corte (Preston et al., 1973), mostraram que o aumento do consumo voluntário nas dietas com o resíduo foram fundamentais para o aumento no desempenho dos animais, de tal forma que a dieta com $50 \%$ da MS na forma do resíduo apresentou valores de ganho de peso aproximadamente iguais às dietas exclusivas de milho.

Todavia, Bovolenta et al. (1998) estudando o resíduo desidratado em dietas de ovinos em crescimento, mostraram efeitos lineares negativos para o consumo de matéria seca a medida que as quantidades do resíduo aumentaram em 0, 20, 40, 60 e $80 \%$ da matéria seca. Torrent et al. (1997), encontraram diminuições no consumo voluntário em ovelhas alimentadas com o resíduo úmido, quando comparado ao feno de alfafa.

Os resultados do estudo da digestibilidade aparente são apresentados na Tabela 4. A digestibilidade da MS não apresentou diferença significativa $(P<0.05)$ entre as dietas testadas. Os baixos valores de digestibilidade encontrados estão ligados principalmente a qualidade do feno utilizado, sendo que este apresentou $37 \%$ do nitrogênio total ligado à porção FDA e portanto considerado indisponível para os ruminantes. Porém, o tratamento $B$ apresentou maior média, podendo levar a uma interpretação que de alguma maneira a inclusão do resíduo proporcionou melhorias na digestibilidade aparente da MS, mas a limitação do consumo de silagem no tratamento $C$, impossibilitou a observação de valores de digestibilidade maiores quando o resíduo foi oferecido em quantidades acima de $33 \%$ da MS da dieta.

A digestibilidade da matéria orgânica $(\mathrm{MO})$ não mostrou variações significativas entre os tratamentos $A$ e $B(P<0.05)$, entretanto o tratamento $C$ indicou valores inferiores quando comparado ao tratamento $B(P>0.05)$, 
mostrando que a inclusão da silagem do resíduo em níveis elevados (67 \% da MS), poderá resultar em diminuições nas quantidades de MO digestível.

Foi observado maiores quantidades de PB digestível nas dietas que receberam o resíduo $(P>0.05)$, indicando a manutenção das características nutricionais do alimento após o tempo de armazenamento, e que a inclusão do resíduo em dietas exclusivas de forragens levaram a aumentos na absorção deste nutriente.

Os valores de digestibilidade encontrados para a FDN não apresentaram diferenças significativas $(P<0.05)$, provavelmente devido as elevadas quantidades deste nutriente encontradas no resíduo. A porção fibra do resíduo apresentou comportamento semelhante ao encontrado na forragem estudada, mostrando o potencial do resíduo com alimento volumoso para ruminantes.

A FDA apresentou menor digestibilidade para o tratamento $B(P>0.05)$, enquanto os tratamentos $A$ e $C$ não mostraram diferenças significativas $(P>0.05)$, embora o resíduo apresente menores quantidades de FDA comparado ao feno, os valores encontrados para o tratamento $\mathrm{C}$ podem ter sido influenciados pelo maior consumo de feno em relação ao resíduo para este tratamento.

Os resultados da literatura que avaliaram a digestibilidade aparente de dietas contendo o resíduo de cervejaria fornecida para ovinos obtiveram aumentos de digestibilidade comparados aos obtidos com forragens. Ovinos alimentados exclusivamente do resíduo úmido ad libitum (Torrent et al., 1997), apresentaram digestibilidades de 60, 64, 57.9 e $41.1 \%$ para MS, MO, FDN e FDA respectivamente. Os valores obtidos foram maiores do que os encontrados por este autor para a digestibilidade de dietas exclusivas com feno de alfafa, porém o consumo voluntário do feno de alfafa foi significativamente maior do que o resíduo $(\mathrm{P}>0.05)$ podendo ser a explicação para os elevados valores de digestibilidade encontrados.

Bovolenta (1998) também obteve aumentos crescentes na digestibilidade da MS, MO, PB, EE e FDN trabalhando com ovinos em crescimento 
alimentados com níveis crescentes do resíduo desidratado, mesmo tendo o consumo voluntário apresentado diminuições crescentes com o aumento dos níveis do resíduo na dieta.

Os valores de digestibilidade aparente encontrado para ovinos alimentados com feno de gramíneas do gênero Cynodon nos estudos revisados variaram em torno de 44 a $60 \%$ para MS e 46 a 63 \% para PB (Berthe, 1992; Dominges et al., 1992; Alayon et al., 1997; Canton et al., 1997), as diferenças nos resultados variam de acordo com a categoria animal e com o estado fisiológico da gramínea, representado através da época de corte.

A diminuição do consumo voluntário quando os animais receberam a dieta C contribuiu para os menores valores de digestibilidade da MS obtidos, estes foram mais próximos dos encontrados para a dieta $A$, houve uma tendência de aumento da digestibilidade da MS quando o resíduo foi oferecido em menores quantidades (tratamento B), porém estes valores foram menores quando o resíduo representou grande parte da MS da dieta. Efeitos lineares positivos para a digestibilidade da PB e para a diminuição na digestibilidade da FDA com o aumento dos níveis do resíduos nas dietas $(P>0,05)$ foram semelhantes aos descritos na literatura.

Estudos que mostram efeitos lineares da digestibilidade aparente com relação ao aumento dos níveis deste subproduto em dietas de ovinos, trabalharam com o resíduo na forma desidratada e geralmente peletizada (Bovolenta et al., 1998), garantido assim maiores consumos do resíduo.

\subsection{Parâmetros ruminais}

\subsection{1. $\mathrm{pH}$}

As variações no $\mathrm{pH}$ do rúmen durante os tempos observados podem ser vistas na Figura 3. Foram notadas diferenças dos valores de $\mathrm{pH}$ entre os tratamentos $(\mathrm{P}<0,05)$, obtendo-se valores médios de 6,26; 5,98e 6,28 (ep = $0,05)$ para $A, B$ e $C$ respectivamente. Os menores valores apresentados no 
tratamento $\mathrm{B}$, podem estar ligados ao maior consumo do resíduo pelos animais, observados durante as primeiras horas após o fornecimento das dietas. O comportamento do $\mathrm{pH}$ observado neste tratamento também foi relatado em outros estudos com ruminantes alimentados com forragens e concentrado (McAllan et al.,1994; Abdalla et al., 1999) e são denominadas de queda após a alimentação.

Figura 3. Variações dos valores de $\mathrm{pH}$ do rúmen de ovinos, em dietas exclusivas de feno de tifton e com a inclusão de $33 \%$ e $67 \%$ da MS na forma de silagem do resíduo de cervejaria.

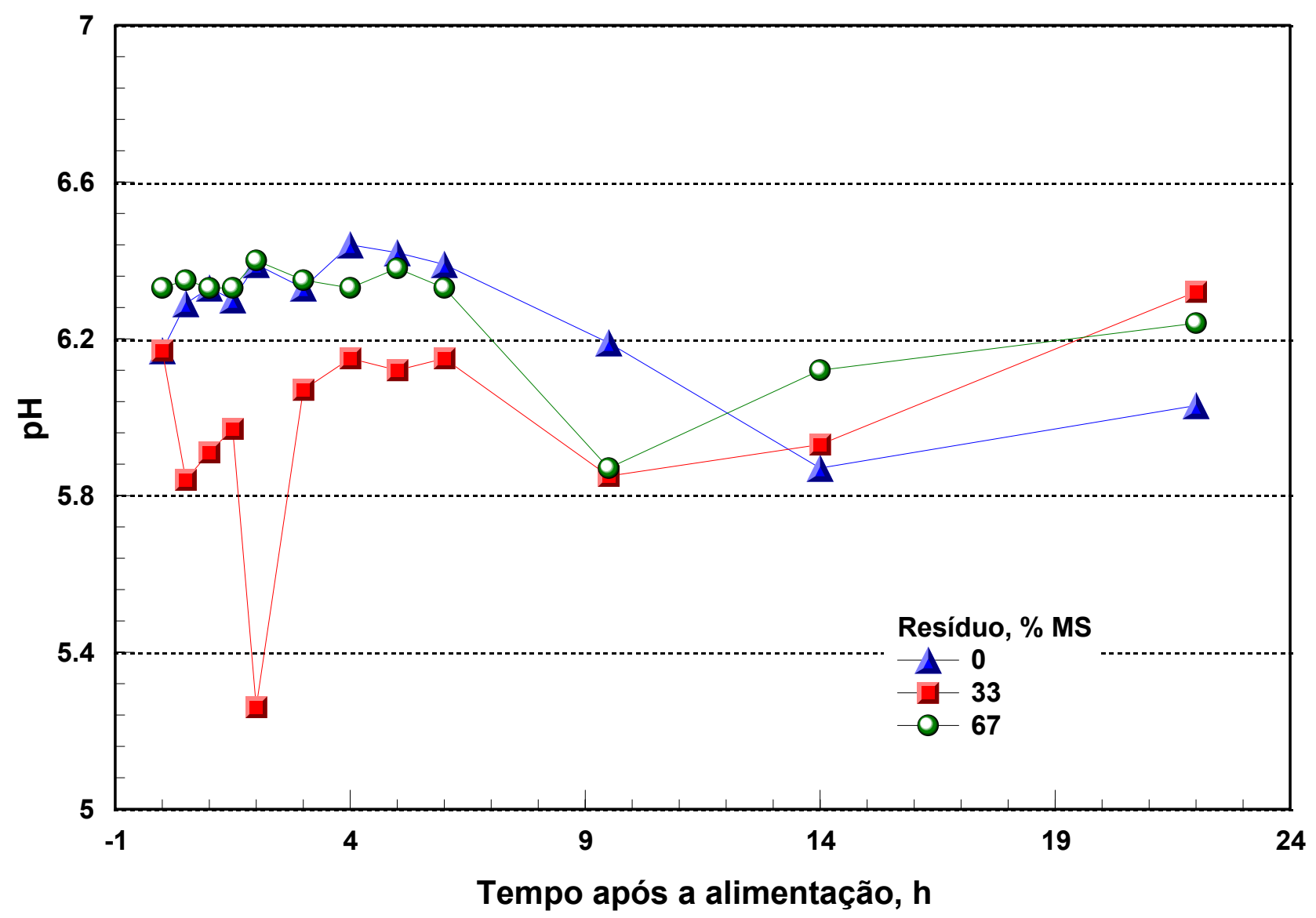

Os tratamentos A e C não apresentaram esta queda, sendo que os valores de $\mathrm{pH}$ permaneceram mais elevados durante as primeiras horas após a 
alimentação, com quedas mais acentuadas somente após a alimentação da tarde (8h). Nas primeiras horas após o fornecimento da dieta matinal, os animais que receberam o tratamento $\mathrm{C}$ apresentaram variações do $\mathrm{pH}$ muito próximas as determinadas no tratamento $A$, demostrando a preferência destes em consumir o feno.

Estas mudanças no pH estão relacionadas principalmente com a solubilidade dos carboidratos presentes no resíduo. (vide Tabela 2) A elevação das quantidades de EE nas dietas de acordo com o aumento das quantidades do resíduo, podem ser responsáveis por alterações dos parâmetros de fermentação ruminal, podendo ser até prejudiciais ao crescimento de algumas espécies de microorganismos importantes para os processos digestivos do carboidratos estruturais.

As maiores quantidades de carboidratos não estruturais no resíduo de cervejaria em relação ao feno de tifton, podem ter sido responsáveis pelo decréscimo dos valores de $\mathrm{pH}$ observado no tratamento $\mathrm{B}$. Carboidratos não estruturais como o amido e açucares mais simples produzem inicialmente ácido propiônico e ácido láctico no rúmen, resultando em queda dos valores de $\mathrm{pH}$ (Stern \& Ziemer, 1993).

Alguns trabalhos com o resíduo de cervejaria como o de Rogers et al. (1986) encontraram queda nos valores de $\mathrm{pH}$ do rúmen para novilhas alimentadas com o resíduo na foram úmida. Estes decréscimos foram encontrados também por outros autores (Jeffrey, 1997; Mertens, 1998), que atribuíram estas alterações ao resultado das mudanças físicas na digestão de fibras de subprodutos em relação às forragens. Estas mudanças estão fortemente ligadas a fatores do tipo consistência do material ruminal, estímulo a salivação e motilidade do trato.

Embora o tratamento $\mathrm{C}$ tenha representado as maiores quantidades do resíduo na MS da dieta, as variações encontradas foram muito próximas das determinadas no tratamento A (100 \% feno de tifton). Esta semelhança pode ser explicada pelo comportamento alimentar dos animais. Os animais que 
receberam o tratamento $\mathrm{C}$, consumiam maiores quantidades de feno nas primeiras horas após o fornecimento das dietas, já no tratamento $B, 0$ comportamento foi oposto, neste caso os animais consumiam toda a silagem do resíduo nas primeiras horas e só depois começavam a consumir o feno. A seletividade dos animais que receberam o tratamento $\mathrm{C}$, limitou as investigações do efeito do resíduo no $\mathrm{pH}$ do rúmen quando oferecido em quantidades elevadas da dieta.

Os maiores consumos de feno pelos animais submetidos ao tratamento $\mathrm{C}$, resultaram nas elevações do $\mathrm{pH}$ ruminal observadas nas primeira horas após a alimentação. Os maiores valores de $\mathrm{pH}$ encontrados podem ser atribuídos ao maior consumo de carboidratos estruturais. Tamminga et al. (1990), trabalhando com vários tipos de fontes protéicas utilizados na alimentação de vacas leiteiras também observaram menores quedas nos valores de $\mathrm{pH}$ de acordo com o tipo de carboidrato estrutural presente e atribuíram estas alterações ao aumento da capacidade tamponante do rúmen, resultando em aumento do $\mathrm{pH}$ e das concentrações de ácidos graxos voláteis (AGV).

A inclusão da silagem do resíduo na dieta apresentou decréscimo significativo do $\mathrm{pH}(\mathrm{P}<0,05)$ apenas após a alimentação da manhã, $2 \mathrm{~h}$, sendo que após a alimentação da tarde, a partir de 6h, não foram notadas diferênças significativas entre os tratamentos $(P>0,05)$, onde as dietas exclusivas de forragem também apresentaram quedas no valores de $\mathrm{pH}$.

Os resultados médios de $\mathrm{pH}$ ficaram a cima de 6,0 na maioria dos tempos observados, com exceção do tratamento $B$, que apresentou valor mínimo de 5,26 as $2 \mathrm{~h}$ após a alimentação. Segundo Slyter (1986) valores abaixo de 6,0 podem ser prejudiciais para o desenvolvimento de espécies celulolíticas, embora no tratamento A (exclusivo de forragens) tenha sido observado valores de 5,87 as 14 h após a primeira alimentação. 


\subsubsection{Nitrogênio amoniacal}

Os teores de nitrogênio amoniacal determinados no fluído ruminal dos seis animais, durante os três períodos experimentais, estão representados na Figura 4. A interação tratamento $x$ tempo de amostragem foi significativa $(P<0,05)$. Demonstrando que os tempos de coleta tiveram efeitos diferentes sobre os tratamentos.

Figura 4.Variações das concentrações de $\mathrm{NNH}_{3}$ em mg.100 $\mathrm{ml}^{-1}$ no fluído ruminal, em diferentes tempos de coleta, para os tratamentos $A, B$ e C. Representados respectivamente por 0, 33 e $67 \%$ da MS da dieta na forma do resíduo de cervejaria

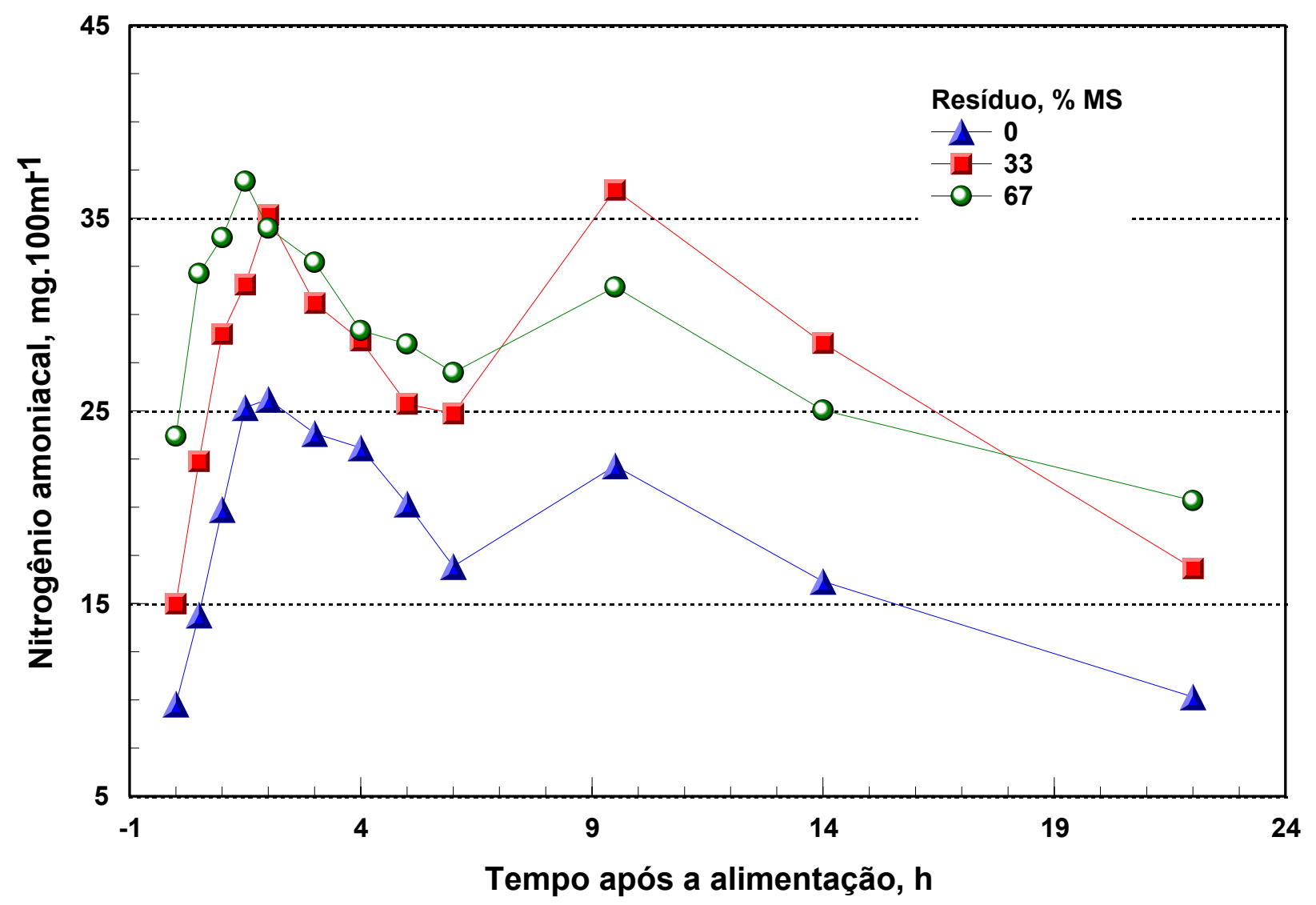

As concentrações de $\mathrm{NNH}_{3}$ no fluído ruminal dos animais apresentaram 
comportamentos semelhantes para os três tratamentos (Figura 4). Os valores médios obtido nas $22 \mathrm{~h}$ de coleta foram de 18,93; 27,03 e 29,61 mg.100 ml $\mathrm{m}^{-1}$ para os tratamentos $A, B$ e $C$ respectivamente. Todos os tratamentos apresentaram elevações nos níveis de $\mathrm{NNH}_{3}$ do rúmen nas primeiras horas após o fornecimento das dietas alcançando valores máximos entre 1,5 a $3 \mathrm{~h}$ após a primeira alimentação. Resultados semelhantes foram encontrados por Abdalla et al. (1999), na substituição da silagem de gramíneas por silagem de plantas de trigo tratada com uréia, em dietas de vacas leiteiras na Inglaterra.

Os padrões de variação diurna foram similares para todos os tratamentos e em nenhum momento as concentrações de $\mathrm{N}^{-\mathrm{NH}_{3}}$ apresentaram quedas

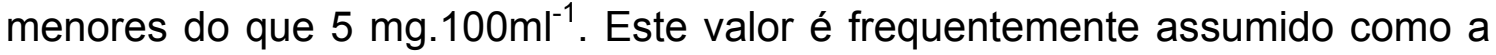
mínima condição necessária para uma máxima atividade microbiana (Satter \& Slyter, 1974).

Os menores picos de amônia foram obtidos para o tratamento $A$ e os maiores para o tratamento $\mathrm{C}$, demostrando as maiores quantidades de $\mathrm{PB}$ disponíveis aos animais e reafirmando os resultados obtidos na avaliação da digestibilidade aparente da PB, que indicaram valores crescentes de digestibilidade protéica com o aumento dos níveis do resíduo na dieta.

Os efeitos das dietas nas concentrações de $\mathrm{N}_{-} \mathrm{NH}_{3}$ apresentaram diferênças significativas nos horários de 0,5; 1,5 e 6h após a alimentação, sendo que as maiores diferênças foram encontradas entre os tratamentos $B$ e $C$ em relação ao tratamento $A$. entre os tratamentos $B$ e $C$ só foram identificados efeitos nos horário de 0,5 e 1,5 h após a alimentação, sendo que após as 6 hs as concentrações de $\mathrm{N}-\mathrm{NH}_{3}$ do tratamento $\mathrm{B}$ mantiveram-se em níveis mais elevados do que no tratamento $C$, que apresentou concentrações semelhantes às do tratamento $A(P>0,05)$. 
O baixo consumo de resíduo pelos animais, quando estes receberam o tratamento $\mathrm{C}$, parece ter influenciado nos menores valores de $\mathrm{N}-\mathrm{NH}_{3}$ encontrados em alguns horários de observação, demostrado nas maiores concentrações encontradas às 9,$5 ; 14,0$ e $22,0 \mathrm{~h}$ para o tratamento $\mathrm{B}$ em relação aos tratamentos $\mathrm{A}$ e $\mathrm{C}$.

Apesar da diminuição do consumo de MS e da seletividade apresentada pelos animais que receberam a dieta $\mathrm{C}$, foram encontradas maiores concentrações médias de nitrogênio disponível no fluído ruminal neste tratamento. O maior fornecimento de PB proporcionado pela inclusão do subproduto, resultou na elevação das concentrações de $\mathrm{N}_{-} \mathrm{NH}_{3}$ no rúmen aumentando a disponibilidade deste nutriente comparado as dietas exclusivas de feno de tifton ( tratamento A).

Uma outra hipótese para explicar os elevados valores de amônia no rúmen, seria o fato das dietas apresentarem baixa energia para o máximo aproveitamento da amônia, resultando nos elevados valores desta no líquido ruminal. Dietas com energia prontamente disponível podem levar a uma utilização mais eficiente do nitrogênio amoniacal (Medeiros, 1992; Chamberlain et al., 1993; Van Soest, 1994) e muitas vezes reduzem os níveis de amônia no rúmen.

Estudos com caprinos (Rai \& Mudgal, 1996) em condições fisiológicas semelhantes aos animais utilizados neste trabalho, obtiveram valores médios de 28,6; 17,$43 ; 14,38$ e 25,57 mg . $100 \mathrm{ml}^{-1}$, em dietas com concentrado mais palha de trigo sem tratamento, com tratamento químico (hidróxido de sódio), com tratamento químico e físico (pressão e temperatura) e com tratamento biológico (celulase), respectivamente.

Rogers et al. (1986), obtiveram maiores concentrações de nitrogênio amoniacal no rúmen de novilhas alimentadas com resíduo de cervejaria na 
forma úmida com relação ao resíduo desidratado, no presente estudo também foi notado um acréscimo das concentrações deste elemento de acordo com a adição do resíduo úmido em dietas exclusivas de forragem. Os autores demostraram que a solubilidade da proteína do resíduo na forma úmida possibilita aumentos na concentração do nitrogênio amoniacal e somente após o tratamento térmico empregado na sua secagem esta proteína apresentou insolubilidade no líquido ruminal.

Apesar da digestibilidade da fração protéica do resíduo no fluído ruminal ter sido estimada em aproximadamente 50 \% (Clark, 1987), as concentrações de $\mathrm{N}-\mathrm{NH}_{3}$ obtidas neste estudo, apresentaram-se elevadas quando foi fornecido grande parte da MS da dieta na forma deste alimento (tratamento $\mathrm{C}$ ). As elevações desta concentração de $\mathrm{N}^{-\mathrm{NH}_{3}}$ na solução ruminal indica maiores absorções de PB pelos animais, mesmo com a baixa disponibilidade desta proteína a degradação ruminal.

\subsection{Degradabilidade "in situ"}

Os valores encontrados para a degradabilidade efetiva da MS após $96 \mathrm{~h}$ de incubação no rúmen dos ovinos, considerando uma taxa de passagem constante de $2 \% \cdot \mathrm{h}^{-1}$ foram respectivamente 55,9; 60,1 e 63,8 (ep = 1,49) para os tratamentos $A, B$ e $C$. O resíduo puro de cervejaria apresentou uma degradabilidade potencial de $69,4 \%$ (ep = 1,49). O aumento da inclusão do resíduo em dietas exclusivas de feno resultou em maiores taxas de desaparecimento da MS durante os tempos de incubação estudados $(P<0,01)$. Estes resultados mostram que o resíduo é mais facilmente colonizado pelos microrganismos do rúmen e mesmo sendo um material que apresentou elevadas quantidades de FDN $\left(599,55 \mathrm{~g} \cdot \mathrm{Kg}^{-1}\right)$, mostrou ser rapidamente colonizado no rúmen. 
A análise de regressão entre os níveis do resíduo e as taxas de degradabilidade efetiva apresentaram efeito linear positivo $(p=0,155 n+53,866$; $\left.r^{2}=0,92\right)$, com maiores taxas de desaparecimento da MS $(p)$ de acordo com o aumento dos níveis da silagem do resíduo na dieta $(n)$. O gráfico representando esta relação pode ser visto na Figura 5.

Figura 5. Regressão linear entre os níveis de inclusão de 0 (A), 33 (B), 67 (C) e $100 \%$ (D) da silagem do resíduo de cervejaria e a degradabilidade efetiva da MS, considerando uma taxa de passagem de $2 \% \cdot \mathrm{h}^{-1}$.

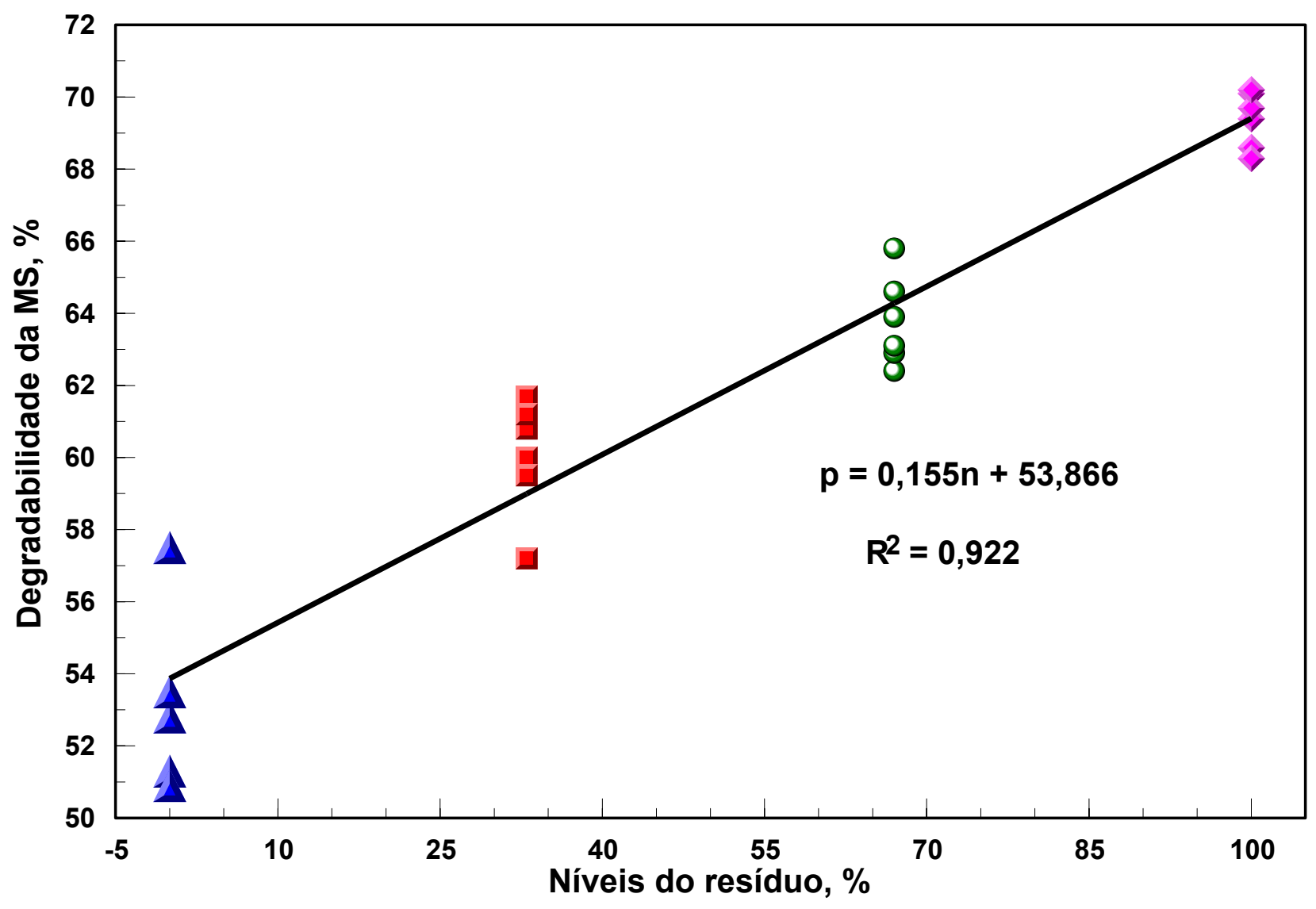

Valores de $64,41 \%$ de degradabilidade MS foram encontrados por Costa et al. (1995) trabalhando com o resíduo úmido em um tempo de incubação de $48 \mathrm{~h}$ 
no rúmen de vacas leiteiras. Comparando a degradabilidade da MS do resíduo na forma seca e úmida, Davis et al. (1983), encontrou valores de 56,3 e 42,9 \%, respectivamente, durante $24 \mathrm{~h}$ de incubação, em dietas para vacas leiteiras contendo $20 \%$ de resíduo de cervejaria prensado.

A maior degradabilidade ruminal do resíduo de cervejaria em relação ao feno, mostrou o diferente comportamento da fibra do resíduo à digestão microbiana, este fato pode estar relacionado com fatores como a densidade da porção fibra e a solubilidade de alguns componentes do resíduo no líquido ruminal. $\mathrm{Na}$ avaliação in vivo, não foram obtido maiores valores de digestibilidade aparente da MS de acordo com o aumento dos níveis do resíduo na dieta. Neste caso não houve diferênças significativas $(P>0,05)$ entre os tratamentos, podendo estar relacionado com a seletividade dos animais e o menor consumo do resíduo quando este fazia parte de grande quantidade da MS da dieta. Os animais consumiram maiores quantidades de feno com relação ao resíduo no tratamento $\mathrm{C}$, notado pelas maiores quantidades do resíduo nas sobras e limitando a real avaliação da digestibilidade aparente da MS para este tratamento.

\subsection{Síntese microbiana}

Os valores do nitrogênio incorporado na massa microbiana não apresentaram diferença significativa $(P>0,05)$ entre os tratamentos estudados, de acordo com o teste de Tukey. As dietas A, B e C em estudo apresentaram valores de $4,60^{\mathrm{a}} ; 4,62^{\mathrm{a}}$ e $5,03^{\mathrm{a}} \mathrm{mg}$ de $\mathrm{Ni}$ por $\mathrm{g}$ de $\mathrm{MS}$ fermentada, respectivamente.

A atividade microbiana parece não ter sido influenciada $(P>0,05)$ pela adição do resíduo de cervejaria às dietas exclusivas do feno de tifton. Os valores de nitrogênio incorporado obtidos foram considerados satisfatórios quando comparados a estudos conduzidos com outras gramíneas.

Trabalhos como o de Bueno (1998) onde foi medida a atividade 
microbiana em 10 substratos de Braquária decumbens submetida a diferentes níveis de adubação, apresentaram valores médios que variaram de 0,44 a 3,22 mg nitrogênio incorporado à massa microbiana.A avaliação da atividade microbiana em diferentes partes da leucena, através da incorporação do ${ }^{32} \mathrm{P}$, foi descrita por Bueno et al. (1999), obtendo valores finais de 1,52; 3,31 e 3,51 mg de nitrogênio incorporado à massa microbiana para caule, folha e folíolo respectivamente .As quantidades de $\mathrm{Ni}$ obtidas por Van Nevel \& Demeyer (1977) variaram entre 18,3 e 31,3 g de Ni por Kg de MO fermentada no rúmen, quando utilizaram gramíneas de clima temperado e alimentos concentrado.

\subsection{Análise por ativação neutrônica}

Os resultados obtidos através da análise por ativação neutrônica do resíduo de cervejaria úmido estão descritos na Tabela 5.

Tabela 5. Concentrações médias $(\mu \mathrm{g} / \mathrm{g})$ de elementos de interesse nutricional no resíduo úmido de cervejaria, coletado em duas indústrias, em diferentes períodos, e analisados por ativação neutrônica.

\begin{tabular}{cccccc}
\hline Elemento & $\begin{array}{c}\text { Média } \\
(\mu \mathrm{g} / \mathrm{g})\end{array}$ & $\begin{array}{c}\text { Desvio } \\
\text { padrão }\end{array}$ & Mínimo & Máximo & $\begin{array}{c}\text { Limite de } \\
\text { detecção } \\
(\mu \mathrm{g} / \mathrm{g})\end{array}$ \\
\hline $\mathrm{K}$ & 508,98 & 21,91 & 400 & 612,2 & 200 \\
$\mathrm{Ca}$ & 4309,06 & 218 & 3420 & 5395 & 500 \\
$\mathrm{Na}$ & 217,01 & 68,63 & $<30$ & 539,73 & 30 \\
$\mathrm{Fe}$ & 275,70 & 43,98 & 128,00 & 539,7 & 10 \\
$\mathrm{Cr}$ & 2,30 & 0,69 & 0,96 & 6,54 & 0,5 \\
$\mathrm{Co}$ & 0,056 & 0,022 & 0,013 & 0,2024 & 0,005 \\
$\mathrm{Mo}$ & 2,66 & 0,28 & 1,87 & 3,98 & 1,00 \\
$\mathrm{Se}$ & 0,54 & 0,19 & $<0,10$ & 1,62 & 0,100 \\
$\mathrm{Zn}$ & 95,71 & 4,36 & 77,35 & 111,67 & 1 \\
$\mathrm{Sr}$ & 41,53 & 2,22 & 29,10 & 52,13 & 10 \\
$\mathrm{Hg}$ & $<1$ & --- & -- & --- & 1 \\
$\mathrm{As}$ & $<1$ & --- & -- & -- & 1 \\
$\mathrm{Cd}$ & $<5$ & --- & -- & -- & 5 \\
\hline
\end{tabular}


Os espectros foram investigados a partir dos valores de energia correspondentes aos elementos de interesse no estudo e através do cálculo das áreas destes picos, pode-se quantificar os elementos. No presente trabalho, consideraram-se importantes elementos envolvidos em reações tóxicas, como o As, $\mathrm{Cd}$ e Hg. Além de outros elementos de interesse nutricional como $\mathrm{K}, \mathrm{Ca}, \mathrm{Fe}$, $\mathrm{Cr}, \mathrm{Co}, \mathrm{Zn}, \mathrm{Mo}$ e Se.

Entre os macrominerais, considerou-se de interesse a avaliação principalmente do $\mathrm{K}$, pois é considerado deficiente no resíduo de cervejaria. Os valores médios de 508,98 $\mu \mathrm{g} / \mathrm{g}$ indicaram baixas concentrações deste elemento quando comparado com os encontrados em outros resíduos como o bagaço de laranja, que apresentaram valores de $9900 \mu \mathrm{g} / \mathrm{g}$, segundo Da Silva Filho et al. (1999), quando submetido à analise por ativação neutrônica. A deficiência em potássio nos ruminantes pode aparecer através de sinais não muito específicos tais como crescimento retardado, decréscimo no consumo de alimento e água. Apesar das quantidades de $\mathrm{K}$ nas forragens serem em geral maiores que os requeridos para animais em pastejo, informações mais recentes indicam que forragens de inverno, ou feno que foi exposto a chuva ou ao sol ou, foi feito com pastagem madura, podem apresentar níveis de potássio abaixo dos adequados para uma boa nutrição.

As quantidades de $\mathrm{Ca}$ encontradas foram relativamente elevadas quando comparado com os valores médios de $1700 \mu \mathrm{g} / \mathrm{g}$ relatados em grande parte dos trabalhos com forragens (Possenti et al., 1992). Os valores determinados mostraram-se intermediários entre os encontrados em subprodutos como o farelo de arroz (400 $\mu \mathrm{g} / \mathrm{g})$, a casca de cevada $(700 \mu \mathrm{g} / \mathrm{g})$ e a casca de algodão $(900 \mu \mathrm{g} / \mathrm{g})$ e o verificado na farinha de peixe $(54700 \mu \mathrm{g} / \mathrm{g})$, descritos por Da Silva Filho et al. (1999).

O resíduo de cervejaria apresentou concentrações elevadas de Se. O Se 
é considerado um elemento importante para os animais ruminantes, principalmente pela suas baixas concentrações nas pastagens tropicais. Um consumo de $0,1 \mu \mathrm{g} / \mathrm{g}$ deste elemento, proporciona uma margem de segurança satisfatória contra variações dietéticas normalmente encontradas por animais em pastejo (Conrad et al., 1985).

As ligações do Se com características reprodutivas dos ruminantes já é comprovada por vários trabalhos científicos, a elevada presença deste elemento no resíduo de cervejaria é um fato que pode justificar a sua utilização na suplementação de animais em pastejo, principalmente fêmeas em reprodução.

Um outro elemento que chamou a atenção foi o $\mathrm{Cr}$, pois apresentou picos bem característico e em quantidades aparentemente mais elevada do que em outros resíduos agro-industriais. $\mathrm{O} \mathrm{Cr}$ faz parte dos microelementos denominados de "novos microelementos" pela evidência da sua essencialidade ter sido descoberta recentemente. Além de estar envolvido na manutenção de colesterol no soro, o $\mathrm{Cr}$ é parte integral do fator de tolerância a glicose em humanos.

O resíduo de cervejaria apresentou baixas concentrações de Co, o limite mínimo indicado para ruminantes é de $0,08 \mu \mathrm{g} / \mathrm{g}$. A baixa concentração deste elemento pode ser preocupante quando o resíduo é fornecido em grande parte da MS da dieta sem alguma suplementação adequada. A hipocobaltose pode se manifestar na forma de anemia, redução de apetite, mudanças no pêlo, degeneração da gordura do fígado e queda do nível de produção de vitamina B12 no sangue e fígado.

As quantidades de Mo determinadas no resíduo ficaram próximas dos valores de 0,1 a $3 \mu \mathrm{g} / \mathrm{g}$ considerados como valores normais nas pastagens, segundo Underwood (1977). O Mo é um componente importante para as enzimas responsáveis pela oxidação das purinas e do metabolismo de ferro nos animais, as pastagens contém sempre concentrações baixas desse mineral. 
Os níveis de $\mathrm{Fe}$ encontrado são considerados intermediários embora estejam abaixo dos avaliados em forragens tropicais no Mato Grosso, que ficaram entre 487 a $553 \mu \mathrm{g} / \mathrm{g}$ (Conrad et al., 1980).

Os teores de $\mathrm{Na}$ nas plantas de um modo geral são insuficientes para atender a exigência dos ruminantes, os valores deste elemento determinado no resíduo de cervejaria foram próximos aos citados pelo National Research Council (1980) para a soja, que é de aproximadamente $200 \mu \mathrm{g} / \mathrm{g}$. O feno de alfafa pode apresentar valores próximos de $700 \mu \mathrm{g} / \mathrm{g}$.

Os elementos tidos como importantes em reações tóxicas como o As, Cd e $\mathrm{Hg}$, mostraram-se em quantidades baixas no resíduo de cervejaria. As concentrações destes três elementos não foram determinadas nas condições experimentais usadas, ou seja, foram consideradas abaixo do limite de detecção do aparelho utilizado. Os valores de As permitidos na alimentação animal estão em torno de $50 \mu \mathrm{g} / \mathrm{g}$ (National Research Council, 1980). Para o Cd o NRC (1980) indica valores de 0,5 $\mu \mathrm{g} / \mathrm{g}$ como limite de tolerância máxima nos alimentos para animais, o que indica que as condições experimentais em que foram conduzidas às análises não foram satisfatórias para a detecção deste elemento, considerando-se o limite de detecção de $5 \mu \mathrm{g} / \mathrm{g}$. O Hg também ficou abaixo dos níveis aceitos pelo National Research Council (1980), que são de 2 $\mu \mathrm{g} / \mathrm{g}$. 


\section{CONCLUSÕES}

A conservação do resíduo de cervejaria na forma de silagem, mostrou ser um processo eficiente em um período de armazenamento de até 60 dias.

A inclusão do resíduo em dietas exclusivas de gramínea para ovinos, limitou o consumo voluntário quando esta foi oferecida em quantidades superiores a $33 \%$ da MS da dieta.

O resíduo de cervejaria apresentou comportamento diferenciado quanto a degradação da MS no rúmen, embora os valores de atividade microbiana medidos através da incorporação do ${ }^{32} \mathrm{P}$, tenham sido muito semelhantes quando comparados com os obtidos para o feno de Tifton.

O resíduo de cervejaria não apresentou quantidades elevadas de elementos com importância tóxicológica animal e humana (As, $\mathrm{Cd}, \mathrm{Hg}$ e Cd).

O resíduo de cervejaria estudado apresentou concentrações satisfatórias de $\mathrm{Se}, \mathrm{Cr}$ e Mo; enquanto que os teores de $\mathrm{K}$, Co e Fe foram considerados insatisfatórios.

Devido aos teores médios de $\mathrm{Cu}$ apresentado nos diversos resíduos estudados, acredita-se que a determinação deste elemento é de fundamental importância quando este resíduo for empregado em dietas de ovinos. 


\section{REFERÊNCIAS BIBLIOGRÁFICAS}

ABDALLA, A.L.; SUTTON, R.H.; PHIPPS, D.J.; HUMPHRIES, D.J. Digestion in the rumen of lactating dairy cows given mixtures of urea-treated whole-crop wheat and grass silage. Animal Science, v.69, p.203-212, 1999.

ALAYON, G.; RAMIREZ, A.; KuVERA, J. Consumo voluntario, digestion ruminal y suministro de nitrogeno microbiano en ovinos pelibuey alimentados con pasto estrella (Cynodon nlemfuensis) y suplementados con follaje de gliricidia (Gliricidia sepium). (Compact disc). In: REUNIÃO DE INVESTIGAÇÃO PECUÁRIA EN MEXICO, 23., Veracruz, 1997.

ALLEN, M.S. Relationship between fermentation acid production in the rumen and the requirement for phisically effective fiber. Journal of Dairy Science, v.80, p.1447-1462, 1997.

ARMENTANO, L.E.; PEREIRA, M. Symposium: Meeting the fiber requirements of dairy cows. Journal of Dairy Science, v.80, p.1416-1425, 1997.

ARMENTANO, L.E.; HERRINGTON, T.A.; POLAN, C.E.; MOE, A.J.; HERBEIN, J.H.; UMSTADT, P. Ruminal degradation of dried brewer's grains, and soybean meal. Journal of Dairy Science, v.69, n.8, p.2124-2133, 1986.

BEEVER, D.E.; HARRISON, D.G.; THOMPSON, D.J.; CAMMELL, S.B.; OSBOURN, D.F. A method for the estimation of dietary and microbial protein 
in duodenal digesta of ruminants. British Journal of Nutrition, v.32, p.99112, 1974.

BOVOlentA, S.; PIASENTIER, E.; PERESSON, C.; MALOSSINI, F. The utilization of diets containing increasing levels of dried brewers'grains by growing lambs. Animal Science, v.66, n.3, p.689-695, 1998.

BUENO, I.C.; VITTI, D.M.; ABDALLA, A.L.; CABRAL FILHO, S.L.; MOULD, F.L.; OWEN, E. Efeito do polivinilpolipirrolidona (PVP) na atividade microbiana ruminal em estudos in vitro de avaliação de plantas taníferas. In: REUNIÃO ANUAL DA SOCIEDADE BRASILEIRA DE ZOOTECNIA, Porto Alegre, 1999. Porto Alegre: SBZ, 1999. p.257.

BUENO, I.C. Comparação entre técnicas "in vitro" e "in situ" de avaliação de braquiária para ruminantes. Piracicaba, 1998. 133p. Dissertação (Mestrado) - Centro de Energia Nuclear na Agricultura, Universidade de São Paulo.

CARDOSO, R.M.; SILVA, J.F.; MOTTA, V.A. Produção de leite de vacas alimentadas com silagem de sorgo suplementada com polpa úmida de cevada. Revista da Sociedade Brasileira de Zootecnia, v.11, n.1, p.38-45, 1982.

CHAMBERLAIN, D.G.; ROBERTSON, S.; CHOUNG, J.J. Sugar versus starch as supplements to grass silage: effects on ruminal fermentation and the supply of microbial protein to the small intestine, estimated from the urinary excretion of purines derivatives, in sheep. Journal of the Science of Food and Agriculture, v.63, p.189-194, 1993. 
CLARK, J.H.; MURPHY, M.R.; CROOKER, B.A. Suplying the protein needs of dairy cattle from by products feeds. Journal of Dairy Science, v.70, n.5, p.1092-1109, 1987.

CONRAD, J.H.; McDOWELL, L.R.; ELLIS, G.L.; LOOSI, J.K. Minerais para ruminantes em pastejo em regiões tropicais. Campo Grande: EMBRAPA, CNPGC, 1985. 90p.

COSTA, M.B.; MATTOS, W.R.; BIONDI, P.; CARVALHO, D.D. Degradabilidade ruminal do resíduo úmido de cervejaria. Boletim da Indústria Animal, v.52, n.1, p.87-94, 1995.

CRINCKENBERGER, R.G.; JOHNSON, B.H. Effects of feeding wet brewers'grains to beef heifers on wintering performace, serum selenium and reproductive performace. Journal of Animal Science, v.54, n.1, p.18-22, 1982.

DAVIS, C.L.; GRENAWALT, D.A.; McCOY, G.C. Feeding values of pressed brewers' grains for lactating dairy cows. Journal of Dairy Science, v.66, n.1, p.73-79, 1983.

DA SILVA FILHO, J.C.; ARMELIN, M.J.; DA SILVA, A.G. Determinação da composição mineral de subprodutos agroindustriais utilizados na alimentação animal, pela técnica de ativação neutrônica. Pesquisa Agropecuária Brasileira, v.34, n.2, p.235-241, 1999.

DE SOETE, D.; GIJBELS, R.; HOSTE, J. Neutron activation analysis. London, Wiley \& Sons, 1972. 836p. 
DOMINGEZ, G.; SENRA, A.; DO ESPIRITUSANTO, S. Nutritive possibilities of star grass silage in ruminants supplemented with two sources of plant protein. Cuban Journal of Agricultural Science, v.26, n.3, p.277-282, 1992.

EASTRINDGE, M.L. Alternative feeds. In: OHIO DAIRY NUTRITION CONFERENCE, Wooster, 1991. Proceedings. Wooster: M.L. Eastridge and Others, 1991. p.49-63.

FEKRY, A.E.; SALEM, O.A.; RAKHA, G.M. Effect of feeding some agroindustrial by-products on body composition and physiological parameters of fat-tailed sheep (Compact disc). In: RUMINANT PRODUCTION IN THE DRY SUBTROPICS: CONSTRAINTS AND POTENTIALS, Cairo, 1989. Proceedings. Cairo: MOA of Egypt; ESAP; EAAP; FAO; ICAMAS; WAAP, 1989.

FISKE, C.H.; SUBBAROW, Y. The colorimetric determination of phosphorus. Journal of Biological Chemistry, v.66, n.4, p.1719-1725, 1925.

GARCES, Y.; KUNLDE, W.; BATES, D.; MOORE, J.; THATCHER, W.; SOLLENBERGER, L. Effects of supplemental energy source and amount of forage intake and performance by steers and intake and diet digestibility by sheep. Journal of Animal Science, v.75, n.7, p.1918-1925, 1997.

GOERING, H.K.; WALDO, D.R. Processing effects on protein utilization by ruminants. In: CORNELL NUTRITION CONFERENCE, Buffalo, 1974. Proceedings. Buffalo: University of Cornell,1974. p.25.

HARRIS, B. Value of high-fiber alternative feedstuffs as extenders of roughage sources. In: ALTERNATIVE FEEDS FOR DAIRY \& BEEF CATTLE, St. Louis, 1991. p.138-145. 
HOFFMAN, P.C.; ARMENTANO, L.E. Comparison of brewers wet and dried grains an soybean meal as suplement for dairy cattle. Nutrition Reports International, v.38, n.3, p.655-663, 1988.

HUTTON, K.; BAILEY, F.J.; ANNISON, E.F. Measurements of the bacterial nitrogen entering the duodenum of the ruminant using Diaminop Melic Acid as a marker. British Journal of Nutrition, v.25, p.165-173, 1971.

JEFFREY, L.F. Effects of feeding nonforage fiber sources on site of fiber digestion. Journal of Dairy Science, v.80, p.1426-1437, 1997.

JOHNSON, C.O.; HUBER, J.T. Storage and utilization of wet brewers grains in diets for lactating dairy cows. Journal of Dairy Science, v.70, n.1, p.98-107, 1987a.

JOHNSON, C.O.; HUBER, J.T. Aerobic storage and utilization of ammoniatrated distillers wet grains for lactating dairy cows. Journal of Dairy Science, v.70, n.7, p.1417-1425, 1987b.

LIMA, M.L. Resíduo de cervejaria úmido: formas de conservação e efeitos sobre parâmetros ruminais. Piracicaba, 1993. 98p. Dissertação (Mestrado) - Universidade de São Paulo.

LIMA, S.; LEBOUTE, E.M. Resíduo seco da industrialização de uva como alimento para caprinos e ovinos. In: REUNIÃO ANUAL DA SOCIEDADE BRASILEIRA DE ZOOTECNIA, 23., Campo Grande, 1986. Resumos. Campo Grande, 1986. p.168.

MAYNARD, L.A.; LOOSLI, J.K.; HINTZ, B.S.; WARNER, R.G. Nutrição animal. 3.ed. Rio de Janeiro: Freitas Bastos, 1984. 736p. 
McALLAN, A.B.; SUTTON, J.D.; BEEVER, D.E.; NAPPER, D.J. Rumen fermentation characteristics and duodenal nutrients flow in lactating cows receiving two types of grass silage with two leves of concentrade. Animal Feed Science and Technology, v.46, p.277-291, 1994.

McDONALD, P.; HENDERSON, N.; HERON, S. The biochimistry of silage. 2.ed. Bucks: Chalcombe Publications, 1991. 340p.

McDOWELL, L.R. Nutrition of grazing ruminants in warm climates. Orlando: Academic Press, 1985. 443p.

MEAD, R.; CURNOW, R.N.; HASTED, A.M. Statistical methods in agriculture and experimental biology. 2.ed. London: Chapman \& Hall, 1993. 415p.

MERCHEN, N.; HANSON, T.; KLOPFENSTEIN, T. Ruminal bypass of brewer's dried grains protein. Journal of Animal Science, v.49, n.1, p.192-198, 1979.

MERTENS, D.R. Creating a system for meeting the fiber requirements of dairy cows. Journal of Dairy Science, v.80, p.1463-1481, 1997.

MERTENS, D.R. NDF: Fiber composition and value of forage with different NDF concentration. In: ANNUAL SOUTHWEST NUTRITION AND MANANGEMENT CONFERENCE, Tucson, 1998. Proceedings. Tucson: The University of Arizona, College of Agricultural, 1998. p.85-99.

MILLER, T.B.; EL HANG, G.A.; PRATT, G. Evaluation of wisky by product 3. Effects of calcium suplements on the digestibility and intake of ruminants diet containing malt distillers grains. Journal of the Science of Food and Agriculture, v.21, p.19-26, 1970. 
NATIONAL RESEARCH COUNCIL. Mineral tolerance of domestic animals. Washington: National Academic Press, 1980. 577p.

NUGENT, J.H.; MANGAN, J.L. Rumen proteolysis in leaf protein, casein and bovine serum albumin. Proceedings of Nutrition Society, v.37, p.48A, 1978.

NATIONAL RESEARCH COUNCIL. Nutrient requeriments of sheep. 5.ed. Washington: National Academy of Science, 1975. 72p.

NATIONAL RESEARCH COUNCIL. Nutrient requeriment of dairy catlle. Washington: National Academy of Science, 1989.

ORSKOV, E.R.; McDONALD, I. The estimation of protein degradability in the rumen from incubation measurement weigthted according to rate of passage. Journal of American Science, v.92, p.449-453, 1979.

PEIXOTO, R.R. Nutrição e alimentação animal. Pelotas: Universidade Federal de Pelotas, 1988. 147p.

PHIPPS, R.H.; SUTTON, J.D.; JONES, B.A. Forage mixtures for dairy cows: the effect on dry-matter intake and milk production of incorporating either fermented or urea-treated whole-crop wheat, brewer's grain, fodder beet or maize silage into diets based on grass silage. Animal Science, v.61, p.491496, 1995.

POSSENTI, R.A.; LOBÃO, A.O.; RIBEIRO, W.R.; DELISTOIANOV, J. Determinação de minerais em forragens e tecidos de bovinos. Boletim da Indústria Animal, v.49, n.2, p.131-144, 1992. 
PRESTON, R.L.; VANCE, R.D.; CAHILL, V.R. Energy evaluation of brewers grains for growing and finishing cattle. Journal of Animal Science, v.37, n.1, p.174-178, 1973.

PRESTON, T.R. Tropical animal feeding: a manual for research workers. Rome: FAO, 1995. cap.9, p.181-264. (Animal Production and Health Paper, 126).

RAI, S.N.; MUDGAL, V.D. Effects of alkali and (or) steam treatment of wheat straw or cellulase augmented concentrade mixture on rumen fermentation in goats. Small Ruminants Research, v.19, p.219-225, 1996.

ROGERS, J.A.; CONRAD, H.R.; DEHORITY, B.A.; GRUBB, J.A. Microbial numbers, rumen fermentation, and nitrogen utilization of steers fed wet or dried brewers grains. Journal of Dairy Science, v.69, p.745-753, 1986.

SAMPAIO, A.A.M.; ANDRADE, P.; OLIVEIRA, M.D.S.; ROSA, L.; ANDRADE, A.T. Uso de rações com diferentes níveis de proteína e fontes de energia na alimentação de bovinos confinados. Fase II. Revista da Sociedade Brasileira de Zootecnia, v.13, n.4, p.528-534, 1984.

SAMPAIO, I.B. Estatística aplicada à experimentação animal. 1.ed. Belo Horizonte: Universidade Fedaral de Minas Gerais, 1998. 221p.

SANTOS, K.A.; STERN, M.D.; SATTER, L.D. Protein degradation in the rumen and amino acid absorption in the small intestine of lactating dairy cattle fed variors protein sources. Journal of Animal Science, v.58, n.1, p.244-255, 1984. 
SARRUGE, J.R.; HAAG, H.P. Análises químicas em plantas. Piracicaba: ESALQ, Departamento de Química, 1974. 56p.

SATTER, L.D.; SLYTER, L.L. Effect of ammonia concentration on rumen microbial protein production in vitro. British Journal of Nutrition, v.32, p.194-208, 1974.

SCHWAB, C.G. In: SOUTHWEST NUTRITION MANAGEMENT CONFERENCE, Arizona, 1994. Proceedings. Arizona: University of Arizona, 1994. p.114.

SILVA FILHO, J.C. Determinação da composição mineral de subprodutos agroindustriais utilizados na alimenteção animal, pela técnica de ativação neutrônica. Pesquisa Agropecuária Brasileira, v.34, n.2, p.235-241, 1999.

SIMABUCO, S.M.; NASCIMENTO FILHO, V.F. Análise instrumental e simultânea por ativação neutrônica. Piracicaba: CENA, 1984. 20p.

SLYTER, L.L. Ability of $\mathrm{pH}$ - selected mixed ruminal microbial populations to digest fiber at various pHs. Appied and Enviroment of Microbiology, v.52, n.2, p.390-391, 1986.

STERN, M.D.; ZEIMER, C.J. Digestible fiber sources fo dairy cattle. In: MINNESOTA NUTRITION CONFERENCE, 53., St. Paul, 1992. Proceedings. St. Paul: Minnesota Extension Service, 1992. p.37-56.

STERN, M.D.; ZIEMER, C.J. Consider value, cost when selecting nonforage fiber. Feedstuffs, v.62, n.2, p.14-21, 1993. 
SUSMEL, P.; STEFANON, B.; MILLS, C.R.; MANUELA, C. Change in amino acid composition of different protein source after rumen incubation. Animal Production, v.49, n.3, p.375-383, 1989.

THOMPSON, G.B.; JOHNSON, R.; HUTCHESON, D. Evaluation of brewers dried grains in finishing rations for cattle. Feedstuffs, v.49, n.50, p.9, 1977.

TORRENT, J.; JOHNSON, D.E.; KUJAWA, M.A. Co-product fiber digestibility: kinetc and "in vivo" assessment. Journal of Animal Science, v.72, p.790795, 1994.

UNDERWOOD, E.J. Trace elements in human and animal nutrition. 4.ed. London: Academic Press, 1977. 545p.

VALLADARES FILHO, S.C.; COELHO DA SILVA, J.F.; LEAO, M.I.; EUCLYDES, R.F.; VALLADARES, R.F.D.; CASTRO, A.C.G. Degradabilidade in situ da matéria seca e proteína de vários alimentos em vacas em lactação. Revista da Sociedade Brasileira de Zootecnia, v.19, n.6, p.512-522, 1990.

VAN NEVEL, C.J.; DEMEYER, D.I. Determination of rumen microbial growth "in vitro" from ${ }^{32} \mathrm{P}$ - labelled phosphate incorporation. British Journal of Nutrition, v.38, p.101-114, 1977.

VAN SOEST, P.J. New chemical procedures for evaluating forages. Journal of Animal Science, v.23, n.3, p.838-845, 1964.

VAN SOEST, P.J.; WINE, R.H. Use of detergents in the analysis of fibrous feeds. IV. Determination of plant cell-wall constituents. Journal of the AOAC, v.50, p.50-55, 1967. 
VITTI, D.M.; SILVA FILHO, J.C.; ABDALLA, A.L. Phosphorus availability for rumen microorganism: effects of diferents sources. Journal of Nuclear Agriculture and Biology, v.17, p.182-183, 1988.

WEST, J.W.; ELY, L.O.; MARTIN, S.A. Wet brewers grain for lactin dairy cows during hot, umid weather. Journal of Dairy Science, v.77, p.196-204, 1994. 